\title{
Review
}

\section{Bile Acids as Building Blocks of Supramolecular Hosts}

\section{Jari Tamminen* and Erkki Kolehmainen}

Department of Chemistry, University of Jyväskylä, P. O. Box 35, FIN-40351, Jyväskylä, Finland Tel.: + 358142602659 , Fax: +358 142602501 .

*Author to whom correspondence should be addressed. E-mail: jatata@cc.jyu.fi

Received: 20 October 2000; in revised form 20 December 2000 / Accepted: 20 December 2000 / Published: 16 January 2001

\begin{abstract}
A review of the use of bile acid-based compounds as building blocks for designing novel supramolecular hosts for molecular recognition is presented. Pharmacological applications and the newest spectroscopic and computational studies of bile acid derivatives are also shortly considered.
\end{abstract}

Keywords: Cyclocholates, cholaphanes, molecular clefts, molecular tweezers, molecular recognition

\section{Introduction}

One of the most important fields in synthetic chemistry is the preparation of molecules which can recognize and bind others and then catalyze transformations of the bound molecules i.e. "artificial enzymes" and the construction of systems which can reproduce themselves or otherwise store and process information at the molecular level [1-20]. Among the most interesting challenges in this area is the design and synthesis of "molecular actuators", molecules that can undergo changes in shape in response to external stimuli and thereby, in principle, perform mechanical work [21-30].

The above mentioned properties of these novel synthetic structures will result not only from the presence therein of the various required elements but also from their relative dispositions in space and the three-dimensional shape of the overall assembly. In other words, spatially separated elements combine to achieve an overall effect in these structures. Hence, there will be a requirement for 
molecules with well-defined geometries in which conformational freedom is kept under close control. This criterion can be met by designs based on rigid frameworks. The steroid nucleus is one of the largest rigid units which is readily available and presents two options for substitution (axial and equatorial) at most positions. There are many steroidal compounds which are commercially available and might be chosen as starting materials for more elaborate frameworks. However, bile acids are the most valuable group of these compounds due to their chemically different hydroxyl groups, enantiomeric purity, unique amphiphilicity, availability, and low cost.

Some reviews on bile acids and other steroidal compounds as architectural components in supramolecular chemistry have been published [8, 11-12, 31-33]. Furthermore, Davis and Wareham have discussed the topic of carbohydrate recognition through noncovalent interactions including many cholic acid-based receptors [16]. It is often necessary to protect hydroxyl groups of the bile acid moiety when constructing different bile acid-based supramolecular structures. Gao and Dias have recently reviewed the selective protection of the various hydroxyl groups of cholic acid and its derivatives using, for example, acetate and trifluoroacetate as protecting moieties [34].

In this review the structure, metabolism, and pharmacological applications of bile acids are first shortly considered. Then the role of bile acid derivatives in constructing molecular and supramolecular assemblies is broadly discussed concentrating on the latest applications while keeping the most important older studies in mind. Finally, the newest spectroscopic and computational studies of bile acid-based compounds are presented.

\section{Structure, Metabolism, and Functions of Bile Acids}

Bile acids are polyhydroxylated steroidal acids obtained from the digestive systems of vertebrates [31]. The most abundant mammalian bile acids are hydroxy derivatives of cholanoic acid (5ß-cholan-24-oic acid 1, Figure 1) [35]. The human bile acid pool consists mainly ( 90\%) of cholic

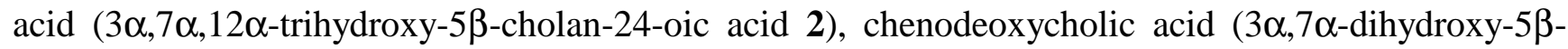

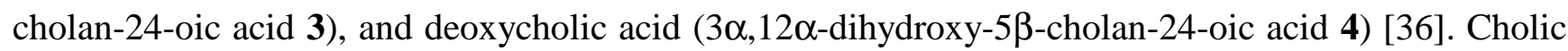
acid and chenodeoxycholic acid are synthesized from cholesterol in the liver via many enzymatic steps. These primary bile acids are conjugated via amide bond to glycine or taurine to give bile salts such as glycocholate 5 and taurocholate $\mathbf{6}$ before secretion into the bile [36]. Bile is stored in the gallbladder and emptied after food intake into the small intestine where bile acids aid in the digestion and resorption of lipids and lipid-soluble vitamins [37]. A part of the primary bile acids is transformed into the secondary bile acids, deoxycholic acid and lithocholic acid ( $3 \alpha$-hydroxy-5 $\beta$-cholan-24-oic acid 7) in the colon [36]. After their absorption in the small intestine and colon, bile acids gain entry to the liver in order to begin their enterohepatic circulation once again. Hofmann has widely considered the role of bile acids in metabolism, their impact on plasma cholesterol levels, and diseases caused by defects in bile acid metabolism [38]. 


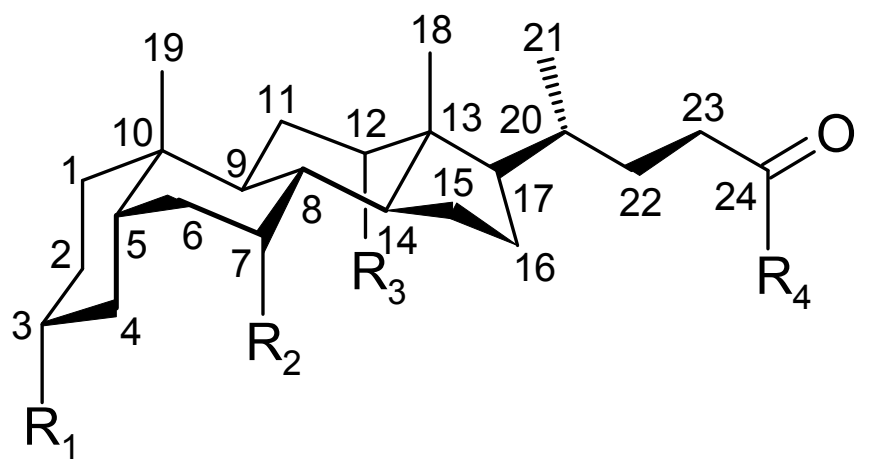

$$
\begin{aligned}
& 1 \mathrm{R}_{1}, \mathrm{R}_{2}, \mathrm{R}_{3}=\mathrm{H}, \mathrm{R}_{4}=\mathrm{OH} \\
& 2 \mathrm{R}_{1}, \mathrm{R}_{2}, \mathrm{R}_{3}, \mathrm{R}_{4}=\mathrm{OH} \\
& 3 \mathrm{R}_{1}, \mathrm{R}_{2}, \mathrm{R}_{4}=\mathrm{OH}, \mathrm{R}_{3}=\mathrm{H} \\
& 4 \mathrm{R}_{1}, \mathrm{R}_{3}, \mathrm{R}_{4}=\mathrm{OH}, \mathrm{R}_{2}=\mathrm{H} \\
& 5 \mathrm{R}_{1}, \mathrm{R}_{2}, \mathrm{R}_{3}=\mathrm{OH}, \mathrm{R}_{4}=\mathrm{NHCH}_{2} \mathrm{CO}_{2}^{-} \\
& 6 \mathrm{R}_{1}, \mathrm{R}_{2}, \mathrm{R}_{3}=\mathrm{OH}, \mathrm{R}_{4}=\mathrm{NHCH}_{2} \mathrm{CH}_{2} \mathrm{SO}_{3}^{-} \\
& 7 \mathrm{R}_{1}, \mathrm{R}_{4}=\mathrm{OH}, \mathrm{R}_{2}, \mathrm{R}_{3}=\mathrm{H}
\end{aligned}
$$

Figure 1. Structures of the most important bile acids and their glycine and taurine conjugates.

\section{Pharmacological Applications of Bile Acids and Their Derivatives}

Cholic acid, chenodeoxycholic acid, and ursodeoxycholic acid (3 $\alpha, 7 \beta$-dihydroxy-5 $\beta$-cholan-24-oic acid) and their conjugates have been used in the treatment of bile acid deficiency and some liver diseases, and in the dissolution of cholesterol gallstones [39]. Antiviral properties of bile acids and their sulfate derivatives [40] as well as antifungal properties of some bile acid esters [41] have been studied with promising results. Nor- and homo-bile acid derivatives have been added to some medicaments in order to improve their absorption [42].

The high specificity and capacity of the bile acid transport systems during their enterohepatic circulation form the basis of the current research efforts to elaborate drug-bile acid conjugates for specific drug targeting to the liver and for improving the intestinal absorption of poorly absorbed or non-absorbed drugs e.g. peptides [36, 43-44]. Kramer and Wess have joined various drug molecules to positions 3, 7, and/or 12 in the steroid nucleus via linker moieties of different functionality, length, and polarity [36]. One example of these conjugates is shown in Figure 2 where oxaprolylpeptide, a drug for liver fibrosis, has been conjugated with modified cholic acid. This conjugate $\mathbf{8}$ has greatly improved ileal absorption compared to the parent drug. Kramer et al. have also synthesized bile acid dimers and trimers which could act as new cholesterol-lowering agents [36] and some bile acid amides which may be used for the treatment or prevention of gallstones or for regulating the lipid components of the gallbladder [45].

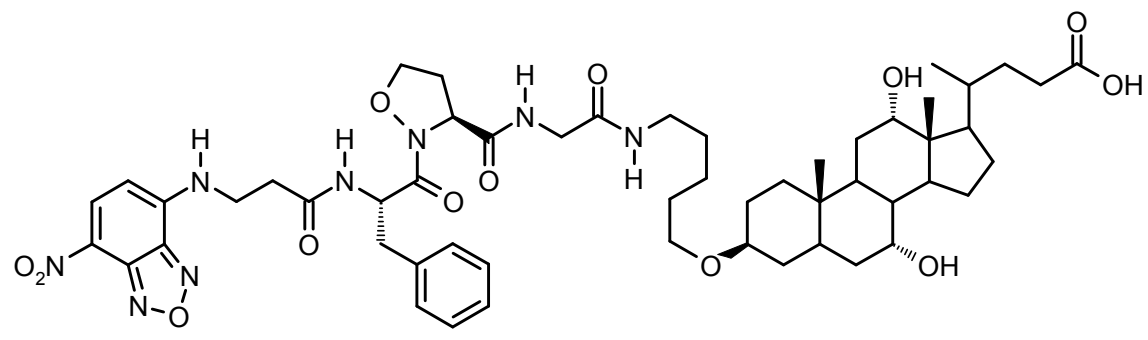

8

Figure 2. A oxaprolylpeptide-bile acid conjugate [36]. 
Other potential medicinal applications for bile acid and their conjugates and complexes are their use in gene therapy [46], as non-opiate analgesics [47], as sensitizers of Gram-negative bacteria to antibiotics [48-49], and as radiopharmaceuticals [50].

\section{Bile Acid-based Molecular and Supramolecular Assemblies}

\subsection{Cyclic Compounds}

The design of novel macrocyclic synthetic receptors with molecular cavities is one of the most important fields in supramolecular chemistry. These host molecules can serve as model compounds for more complex biological systems and are important, for example, for molecular recognition of substrates in enzymatic processes. Typically macrocycles bind substrates either in their defined cavity or above their plane [51].

\subsubsection{Cyclocholates}

Cyclocholates are macrocyclic polyesters (macrolactones) with two to six steroid units formed by head-to-tail cyclization of the bile acids. The most general procedure for the synthesis of these cyclic oligomers has been to prepare them from monomeric or linear dimeric derivatives of bile acids by modified Yamaguchi macrolactonization [52] using DCBC (2,6-dichlorobenzoyl chloride) and DMAP (4-N,N-dimethylaminopyridine) as coupling reagents (Scheme 1) [53-61]. Gao and Dias have reported [62] the macrolactonization of lithocholic acid using DCC (dicyclohexylcarbodiimide) instead of DCBC in cyclization process. Due to the absence of the competitive benzoylation of the $3 \alpha-\mathrm{OH}$, a higher yield of cyclotrimer was obtained compared to Yamaguchi reaction of the same compound [54, $58]$.

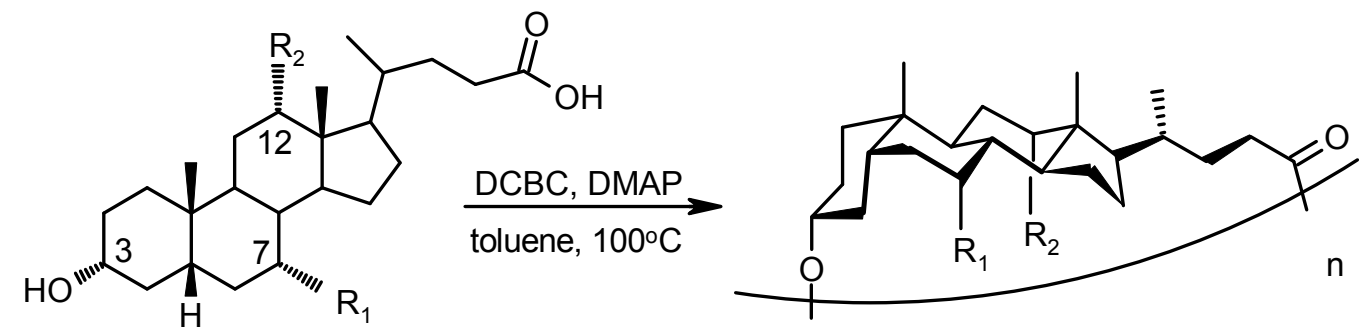

Scheme 1. Yamaguchi macrolactonization procedure for cyclocholates.

Bonar-Law and Sanders have investigated syntheses, self-functionalization, and binding properties of the cyclocholate-capped porphyrins (Figure 3) [63-69]. These compounds bind a variety of functionalized amines such as morphine [63, 64, 66] and some complex alcohols and polyols [67]. 


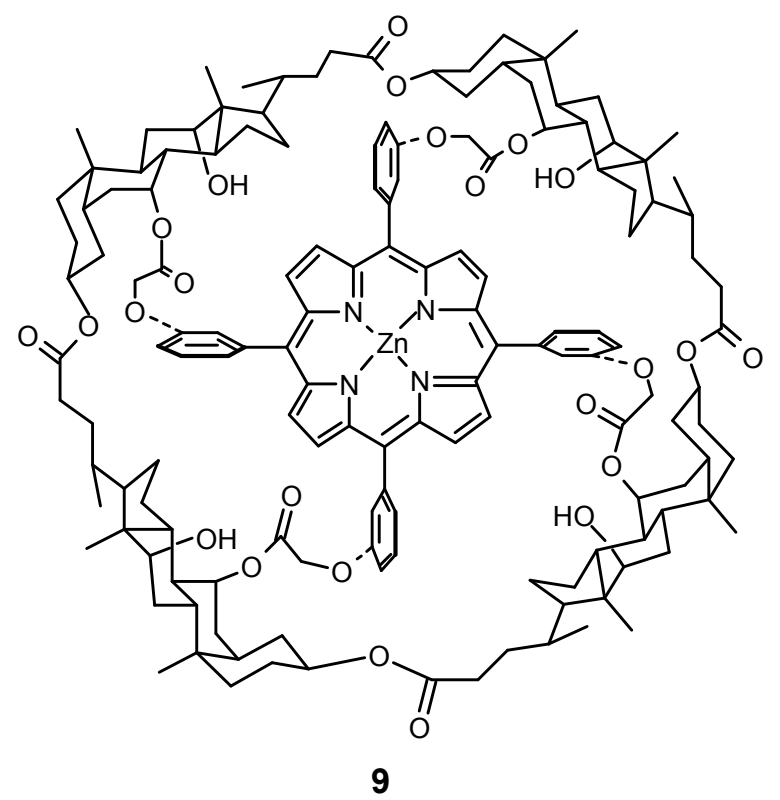

Figure 3. A cyclocholate-capped porphyrin [64].

Lappalainen et al. have studied molecular recognition properties of cyclic cholanoates by the ${ }^{1} \mathrm{H}$ NMR titration method using anisole [53] and ferrocene [55] as guest. The $7 \alpha-$ and $12 \alpha-$ trifluoroacetoxy substituted cholanoate triolides showed clear molecular recognition properties towards anisole and the formation of 1:2 adducts between ferrocene and cyclic triolides were also observed.

Cyclization reactions described above have been performed under kinetic control and represent the conventional irreversible chemistry. Brady and Sanders have developed an efficient and rapid method for the synthesis of the cyclocholates from suitable monomers by transesterification under reversible equilibrium conditions in toluene using potassium methoxide-(dicyclohexyl-18-crown-6) complex as a catalyst [70-71]. This thermodynamically-controlled transesterification process can be labelled "living macrolactonization" because in the equilibrium reaction mixture the individual cholate components rapidly make and break bonds in ever changing relationships with new partners (Scheme 2).

It is possible to influence the distribution of different cyclic oligomers in an equilibrium mixture by adding the alkali metal ( $\mathrm{Li}, \mathrm{Na}, \mathrm{K}, \mathrm{Cs}$ ) iodides to the monomer solution prior to the addition of the catalyst. The equilibrium shifts reflect the relative abilities of the different macrocycles to bind the metal ions and thus result in the selection of the best host. The general trend observed was that the small ions favoured the formation of the large rings, whereas the addition of cesium shifted the distribution towards smaller rings [71]. Brady and Sanders have later quantified the metal ion binding properties of these cyclocholates and some monomeric bile acid derivatives by ESI mass spectroscopy [72]. They observed that ion-binding by the macrocyclic derivatives was markedly different from that by the monomers. This indicates that the presence of the cavity significantly changes the binding profile. 


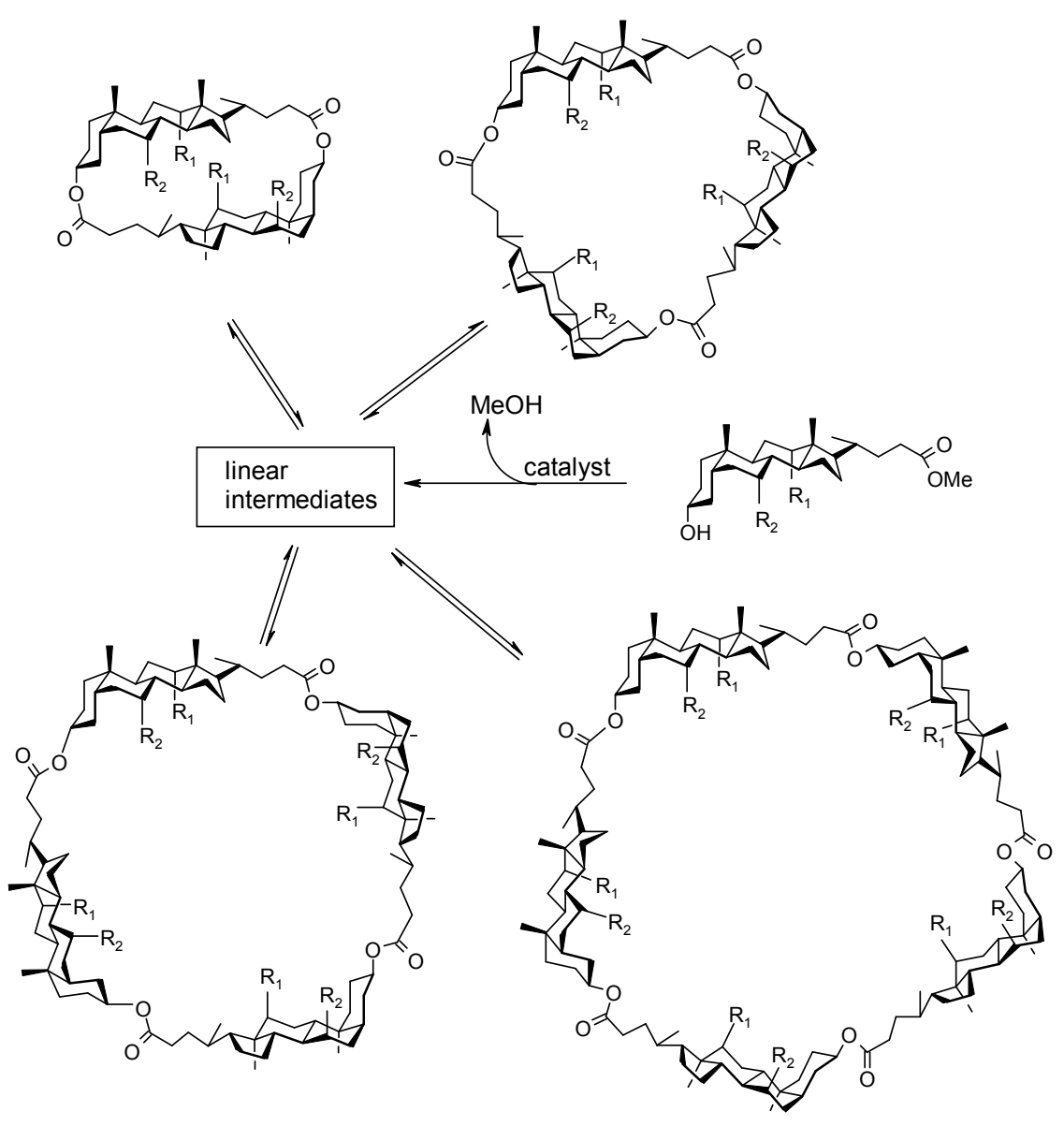

Scheme 2. An equilibrating mixture of cyclic oligomers in "living macrolactonization" process [71].

\subsubsection{Cholaphanes}

Cholaphanes are bile acid-based macrocycles that consist of two to four bile acid units joined together by various spacer groups. Bonar-Law and Davis et al. have comprehensively studied cholaphanes: their synthesis, NMR spectroscopy, molecular mechanics calculations, and their binding of carbohydrate derivatives in organic solvents [16, 73-76]. Davis et al. have continued these studies by preparing some cyclocholamides [77-78]. The moderate flexibility and limited solubility in organic solvents of these cholaphanes have reduced their binding properties. Davis et al. have therefore elaborated a new generation of cholaphanes with externally directed alkyl chains promoting their solubility in chloroform, and with truncated side-chains reducing their conformational freedom [79]. In Figure 4 is illustrated one of these novel macrocycles $\mathbf{1 0}$ which is freely soluble in $\mathrm{CDCl}_{3}$ and possesses very little flexibility. This cholaphane forms a 1:1 complex with octyl $\beta$-D-glucoside in $\mathrm{CDCl}_{3}$ with an association constant $K_{\mathrm{a}}=1560 \mathrm{M}^{-1}$. It also proved able to extract methyl $\beta$-D-glucoside from aqueous solutions into $\mathrm{CHCl}_{3}$ [79]. 


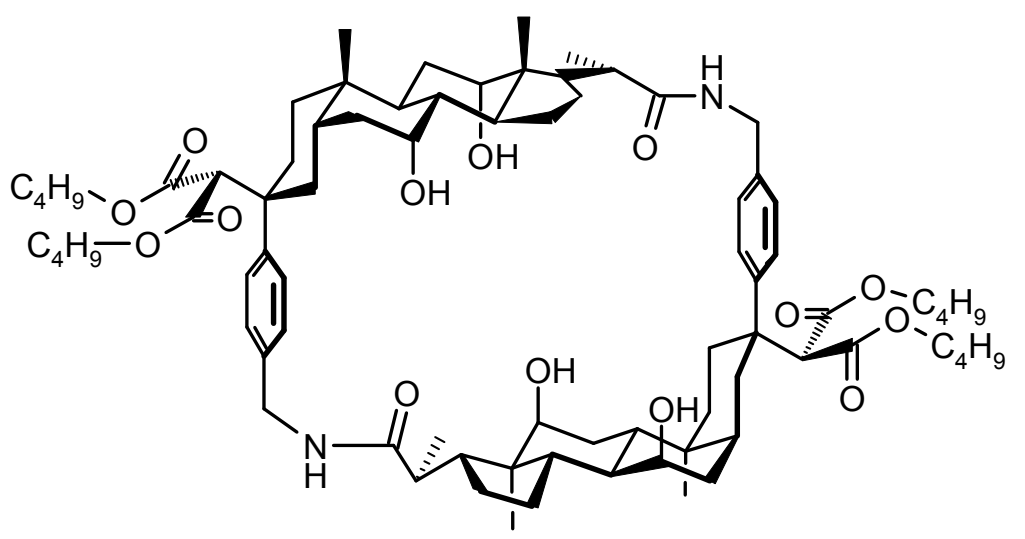

10

Figure 4. A novel, more soluble and less flexible cholaphane [79].

Albert and Feigel have synthesized various steroidal cyclopeptides by joining two molecules of $3 \alpha-$ aminolithocholic acid or its acetoxy derivatives to two phenylalanine monomers [80] or dimers [81] (11a-c, Figure 5). They have studied the conformations of the peptide parts of these macrocycles and observed that the substitution of the cholanic surfaces by acetoxy groups influences the conformation of the peptide chains [81]. They have also determined the crystal structure of one of these cyclopeptides and found intramolecular attraction between steroid and peptide parts of this macrocycle [82].

Pandey and Singh have synthesized a cholic acid-based cholaphane 12 including an ethylenediamine bridge and terephthalate spacer group [83]. The synthetic route leading to this cholaphane is described in Scheme 3. The cyclization step from steroidal bis-bromoacetate $\mathbf{e}$ and bis-cesium terephthalate $\mathbf{f}$ in DMF led to 12 in $95 \%$ yield.

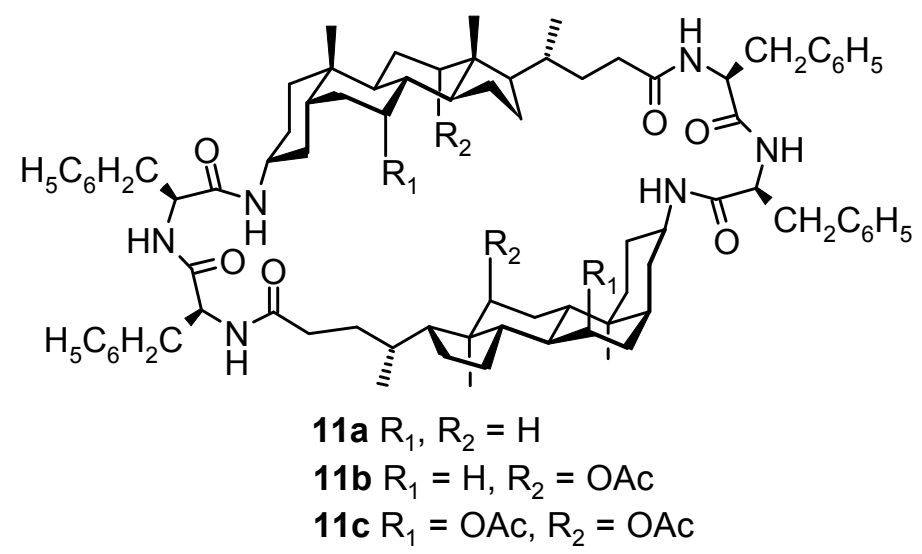

Figure 5. Steroidal cyclopeptides [81-82]. 


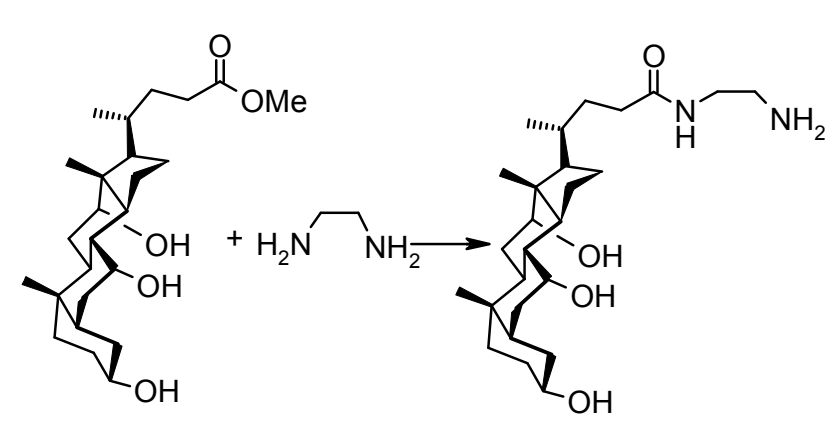

a b

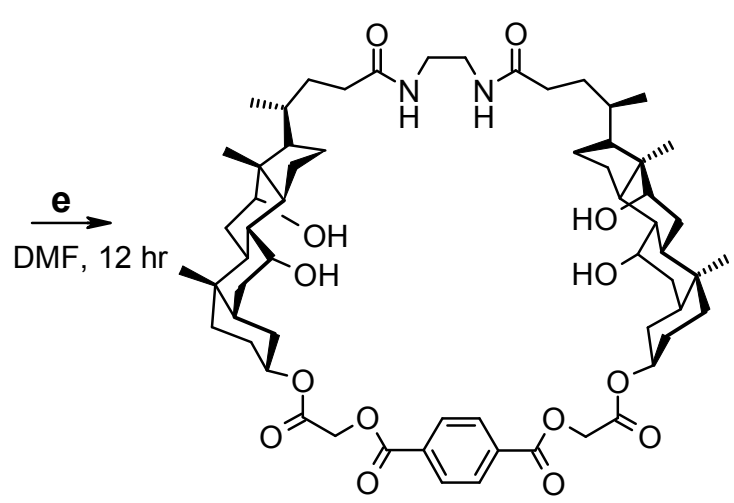

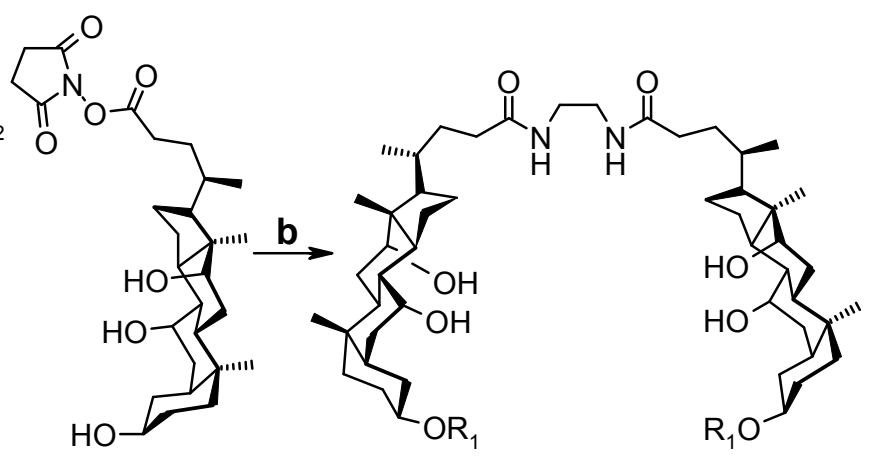

d: $\mathrm{R}_{1}=\mathrm{H}$

e: $\mathrm{R}_{1}=\mathrm{COCH}_{2} \mathrm{Br}$<smiles>O=C(O[Na])c1ccc(C(=O)O[Ga])cc1</smiles>

f

Scheme 3. The synthetic route to cholaphane 12 [83].

We have synthesized four novel lithocholic acid based, ethane-1,2-diol [84] or piperazine [85-86] bridged cholaphanes $(13,14 \mathrm{a}-\mathrm{c}$, Scheme 4) where the ring were closed by terephthalic acid [84-85] or isomeric pyridine dicarboxylic acids [86] using Yamaguchi cyclization [52] procedure. The 13C-NMR measurements and semi-empirical PM3 studies suggested, together with MS data, that 13 is a tetrameric structure and 14a a dimer [84-85]. Furthermore, ESI MS measurements unambiguously revealed that $14 \mathrm{~b}$ is a dimer and $14 \mathrm{c}$ a hexamer [86]. 


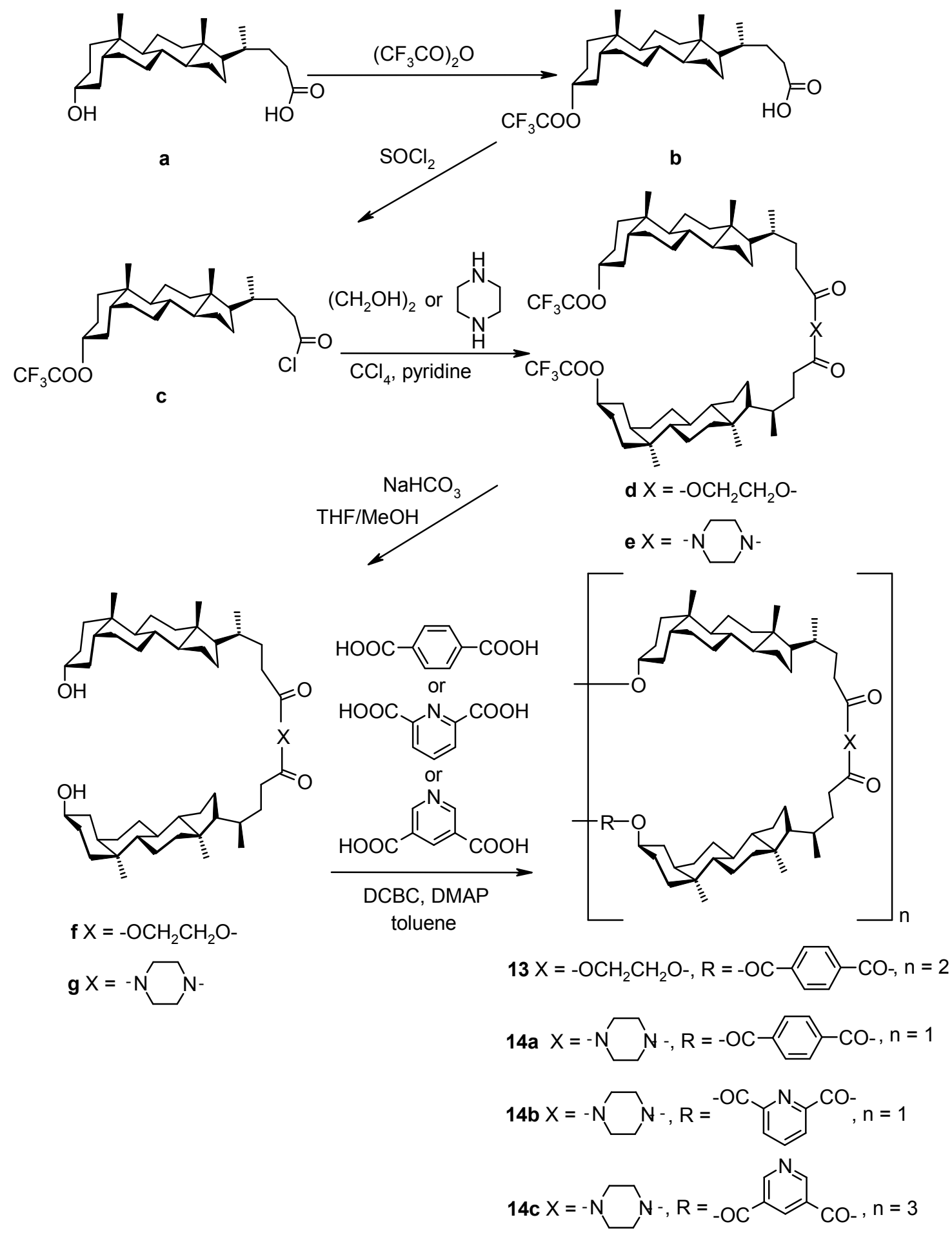

Scheme 4. The synthetic route to cholaphanes 13 [84] and 14a-c [85-86].

\subsubsection{Other Cyclic Structures}

Maitra et.al. have synthesized bile acid-based molecular boxes by attaching two molecular arms to two hydroxyl groups of deoxycholic acid and finally bridging them with a third linker unit [87]. They hoped that these compounds could encapsulate guest molecules to formed cavity but later calculations 
showed that one of the aromatic rings of the arms protrudes inside the cavity and block the entry of any guest [88].

Maitra et al. have also prepared bile acid-based crown ethers (aza crown ethers 15a-c and cholacrowns 16a-b, Figure 6) and observed that their binding affinity towards $\mathrm{Rb}^{+}$and $\mathrm{K}^{+}$ions was greater than to other alkali metal ions. This provides opportunities for the construction of potential alkali metal ion sensors [89-90].

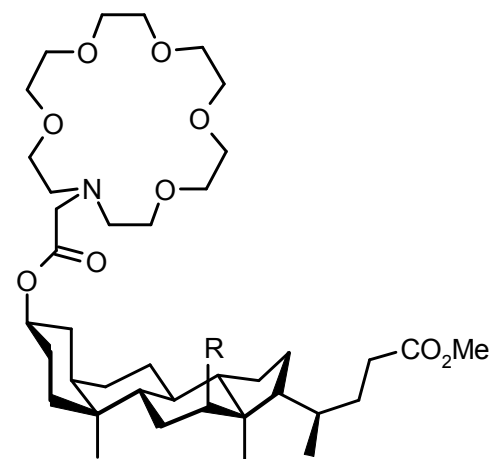

15a R = 2-naphthoyl

15b R = 1-pyrenoyl

15c $\mathrm{R}=\mathrm{OH}$

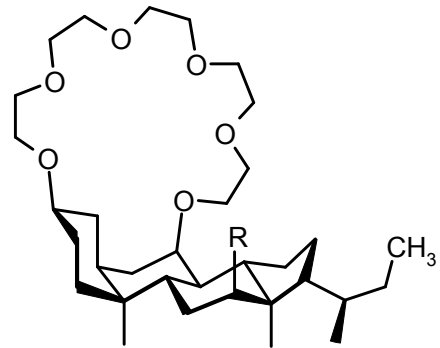

16a R = 1-pyrenoyl

$16 \mathrm{~b} R=\mathrm{OH}$

Figure 6. Bile acid-based aza crown ethers 15a-c and chola-crowns 16a-b [90].

Kohmoto et al. have reported [91] the first synthesis of the steroidal triply-bridged cyclophanes using cholic acid derivatives as bridge units. One of these cyclophanes $\mathbf{1 7}$ is presented in Figure 7. This rather flexible macrocyclic hexaol binds to several organic guest molecules, such as nitrophenols, glycopyranosides, and alanines. Moderate enantioselectivity for $\mathrm{N}$-Z-phenylalanine was observed.

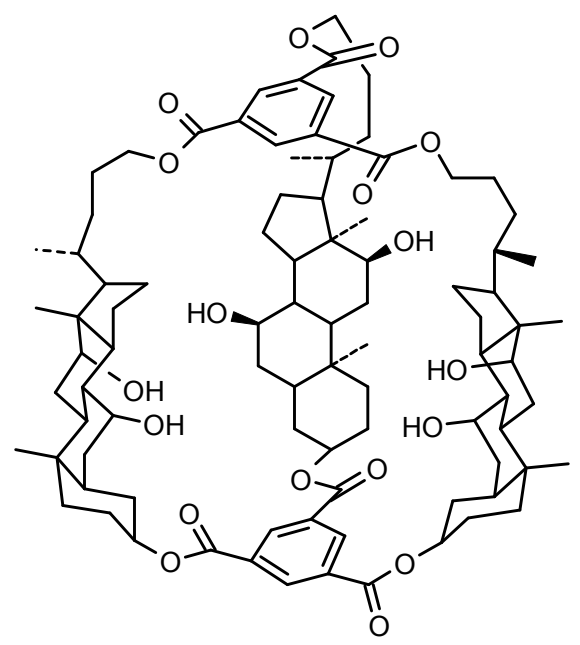

17

Figure 7. A steroidal triply-bridged cyclophane containing bile acid moieties [91]. 
Irie et al. have designed [92] a regioselective macrocyclization method for methyl cholate, using dimethyl $\alpha, \alpha, \alpha^{\prime}, \alpha^{\prime}$-tetramethyl- $m$-xylylenedicarbamate. The double trans-esterification resulted in the formation of both the regioisomeric cyclophanes 18a-b represented in Figure 8. These steroidal carbamoyloxa-bridged cyclophanes are first example of a pair of the regioisomeric cyclophanes.

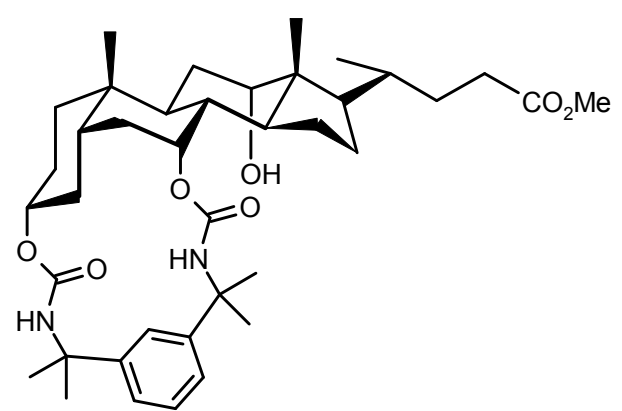

$18 a$

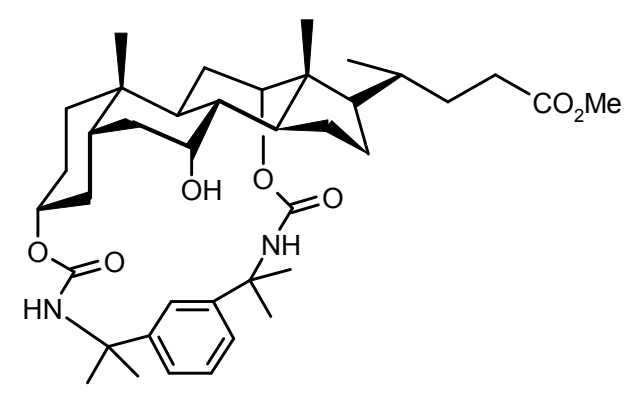

$18 b$

Figure 8. A pair of regioisomeric cyclophanes [92].

Kikuchi and Murakami [93] have designed and synthesized artificial cell-surface receptors (19a-e, Figure 9) bearing four bile acid moieties covalently placed on a tetra-azaparacyclophane skeleton. These cyclophanes bind effectively several naphthalene derivatives in both bilayer membranes and aqueous solutions.

Davis et al. have synthesized a steroid-based cryptand (20, Figure 10) which could form 1:1 complexes with fluoride, chloride, and bromide anions [94].

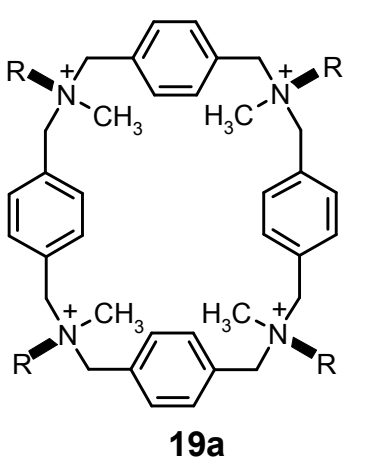

$19 a$

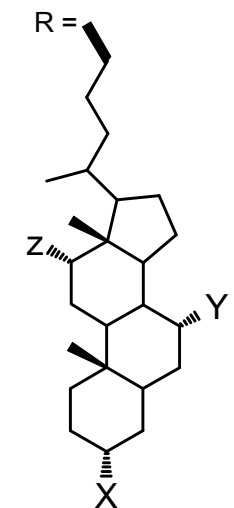

19a $X, Y, Z=O H$

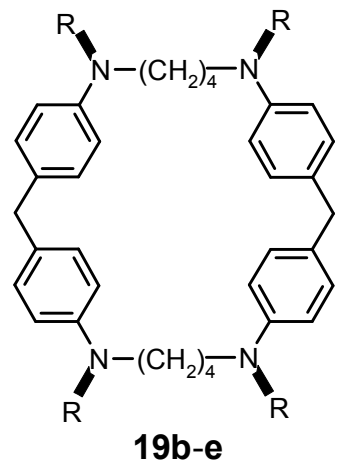

$19 b-e$

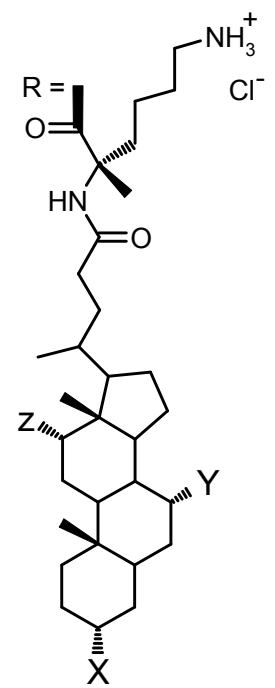

$19 b X, Y, Z=O H$

19c $X, Z=\mathrm{OH}, Y=\mathrm{H}$

19d $X=O H, Y, Z=H$

19e $X, Y, Z=H$

Figure 9. Artificial cell-surface receptors bearing bile acid moieties [93]. 


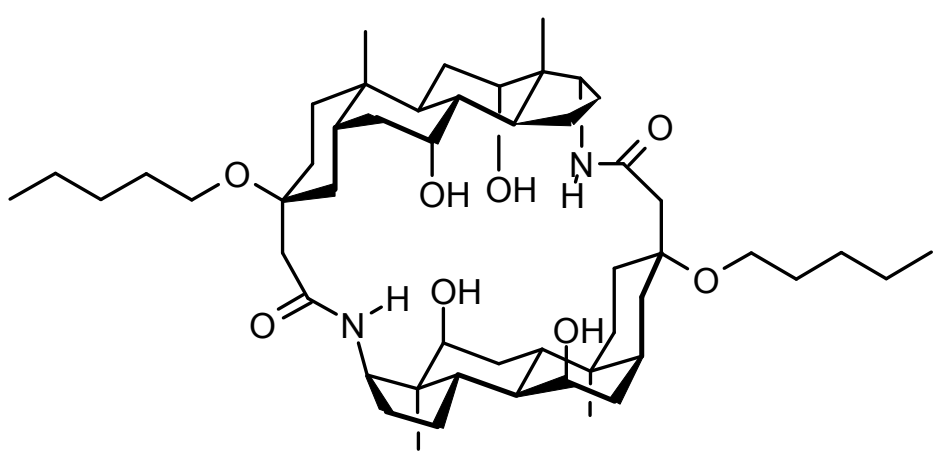

20

Figure 10. A steroid-based cryptand [94].

\section{2. Acyclic Compounds}

\subsubsection{Cleft-type Structures}

An important class of acyclic receptors is formed by cleft-type compounds which can wrap around a substrate molecule. This resembles biological enzyme-receptor binding processes where a substrate is often encapsulated within an enzyme groove [51]. In order to create a molecular cleft, it is highly desirable to have a rigid podand and a spacer unit where the rotation of the podand along the spacerpodand single bond is restricted [95]. The spacers are often formed from fused cyclic rings such as aryl groups and cyclohexanes [51].

The concept of linking two cholic acid molecules to form an acyclic cleft was first reported by McKenna et al. [96]. This was also the first dimeric bile acid-based framework ever published. Kohmoto et al. have synthesized a cleft-type host molecule (21, Figure 11) possessing a cholic acid moiety as a podant from the condensation of naphthalene-1,4,5,8-tetracarboxylic acid dianhydride with a $3 \alpha$-aminocholanoate derivative [95]. Based on ${ }^{1} \mathrm{H}$-NMR spectrometric titration, this receptor was found to associate with 2,6-bis(hydroxymethyl)naphthalene with the binding constant of $91 \pm 9 \mathrm{M}^{-1}$ with a host-guest ratio of 1:1. Conformational analysis of the host molecule in the absence and presence of guest was carried out by variable temperature ${ }^{1} \mathrm{H}-\mathrm{NMR}$ studies. It was observed that in the absence of guest, the conformation of the host was flexible and it adopted two stable conformations at $213 \mathrm{~K}$ (A and $\mathbf{B}$, Figure 11). The cleft-type conformation of host (C, Figure 11) was induced by the inclusion of the 2,6-bis(hydroxymethyl)naphthalene molecule. The guest molecule associated parallel to the diimide part of host. The hydrogen bonding between the hydroxyl groups of host and guest was suggested as the driving force for the formation of the cleft-type structure. 


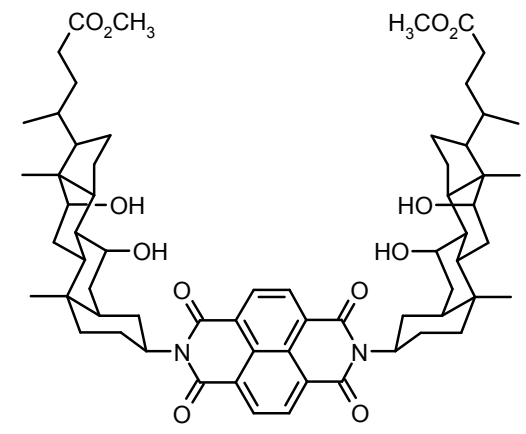

A

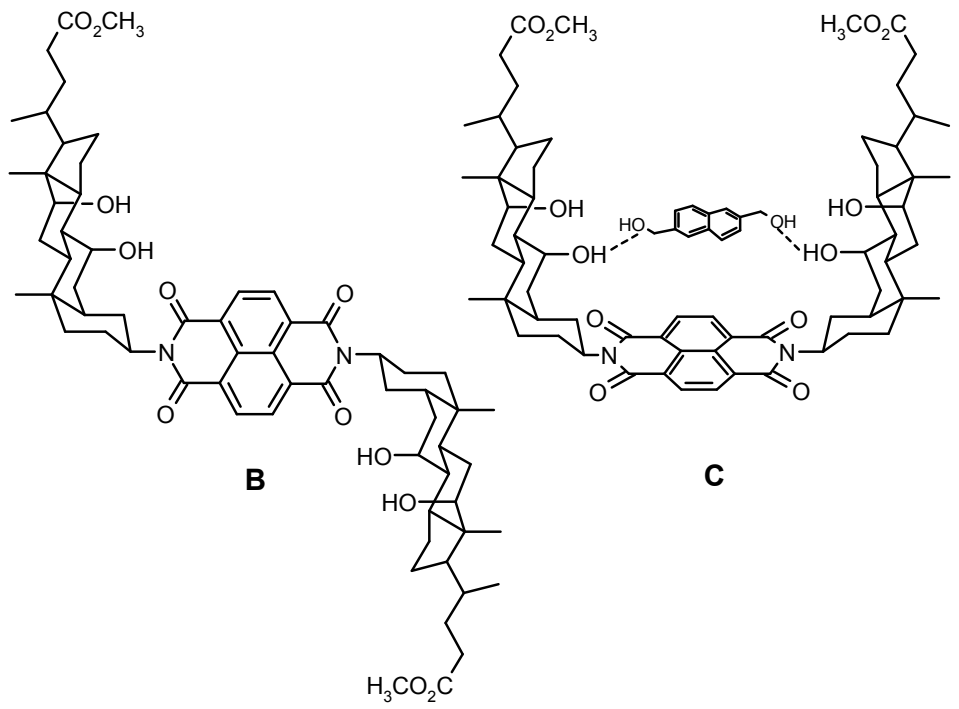

21

Figure 11. Two stable conformations $\mathbf{A}$ and $\mathbf{B}$ of the free host molecule $\mathbf{2 1}$ and the cleft-type conformation $\mathbf{C}$ induced by the inclusion of the 2,6-bis(hydroxymethyl)naphthalene [95].

We have synthesized lithocholic acid-based molecular clefts and investigated their conformational preferences and $\mathrm{Ag}^{+}$-cation binding properties both experimentally by NMR measurements and theoretically by MO calculations [84-85, 97-99]. The structures and yields of these open dimers 22a-i, 23a-c are presented in Figure 12. These dimers were synthesized from their precursor compounds (f and $\mathbf{g}$, Scheme 4) and corresponding aryl chlorides in toluene using DMAP or pyridine to bind $\mathrm{HCl}$ formed in reaction.

The cleft-type structure of these compounds was suggested by semi-empirical (PM3 level) calculations [85, 98-99]. Theoretical calculations and NMR measurements of the synthesized $\mathrm{Ag}^{+}-$ complexes of pyridine- $n$-carboxy $(n=2-4)$ derivatives 22d-f and 23a-c of lithocholic acid-based dimers showed that the coordination behaviour of the $\mathrm{Ag}^{+}$-cation is dependent on the isomerism of the pyridine- $n$-carboxy moiety $[85,98]$.

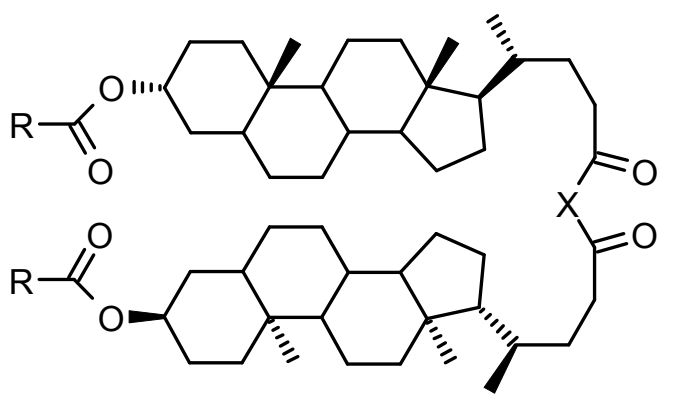

22a-i, 23a-c

$\begin{array}{ll} & \text { R } \\ \text { 22a } & \text { 2,6-dichlorophenyl [97] } \\ \text { 22b } & \text { 2-naphthyl [97] } \\ \text { 22c } & \text { 1-pyrenyl [97] } \\ \text { 22d } & \text { 2-pyridine [98] } \\ \mathbf{2 2 e} & \text { 3-pyridine [98] } \\ \mathbf{2 2 f} & \text { 4-pyridine [98] } \\ \mathbf{2 2 g} & \text { 2-acetoxyphenyl [99] } \\ \mathbf{2 2 h} & \text { 3-acetoxyphenyl [99] } \\ \mathbf{2 2 i} & \text { 4-acetoxyphenyl [99] } \\ \mathbf{2 3 a} & \text { 2-pyridine [85] } \\ \text { 23b } & \text { 3-pyridine [85] } \\ \text { 23c } & \text { 4-pyridine [85] }\end{array}$

$\begin{array}{ll}\text { X } & \mathbf{y .}^{\text {a }} \\ \text { et.glyc. } & 30 \\ \text { et.glyc. } & 72 \\ \text { et.glyc. } & 47 \\ \text { et.glyc. } & 17 \\ \text { et.glyc. } & 28 \\ \text { et.glyc. } & 19 \\ \text { et.glyc. } & 3 \\ \text { et.glyc. } & 3 \\ \text { et.glyc. } & 2 \\ \text { pipe. } & 13 \\ \text { pipe. } & 48 \\ \text { pipe. } & 51\end{array}$

Figure 12. Structures and yields of bile acid based open-chain dimers 22a-i and 23a-c. ${ }^{\mathrm{a}}$ yield $(\%),{ }^{\mathrm{b}}-\mathrm{OCH}_{2} \mathrm{CH}_{2} \mathrm{O}-,{ }^{\mathrm{c}}$ doubly unprotonated piperazine. 
One class of the molecular clefts is molecular tweezers where the heads of the cleft, often aromatic, have a spatial arrangement such that they can form a sandwich-type structure with guest molecules through $\pi$-stacking and hydrogen bonding interactions [88]. Maitra et al. have synthesized various bile acid-based semi-rigid molecular tweezers in which the pyrene units were joined to $3 \alpha$ - and $12 \alpha-$ hydroxyl groups, and studied the binding properties of these tweezers with polynitroaromatic compounds [88, 100-101].

Later they prepared three novel bile acid-based tweezers (bis-pyrene tweezers 24a, bis-guaiazulene analogy 24b, and hybrid tweezers 24c, Figure 13) and studied solvent effect in molecular recognition by determining the binding constants of these tweezers with picric acid (2,4,6-trinitrophenol) in different solvents using straightforward extraction-based protocol [102]. They found that the association between flexible, electron rich aromatic tweezers and an electron deficient aromatic molecule like picric acid is favoured in a medium with a low polarity such as $\mathrm{CCl}_{4}$ or benzene compared to $\mathrm{CHCl}_{3}$ or $\mathrm{Cl}_{2} \mathrm{HCCHCl}_{2}$.

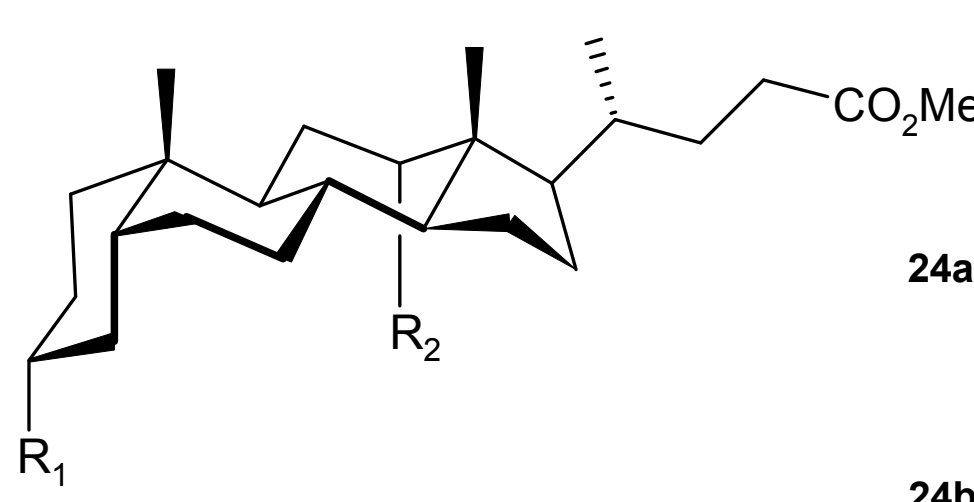

$\mathrm{R}_{1}$

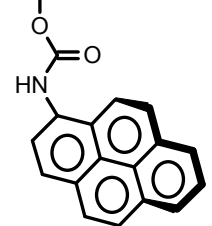

24b

24c

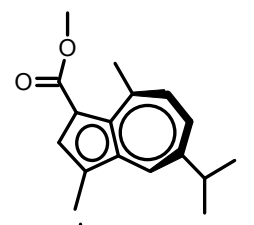

$\mathrm{R}_{2}$
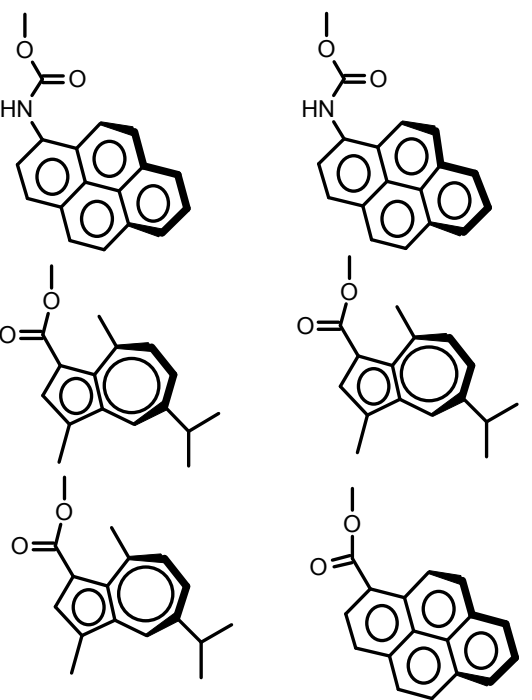

Figure 13. Novel bile acid-based molecular tweezers [102].

Rao and Maitra have also designed and synthesized a bile acid-based molecular tweezers (25, Figure 14) containing a pair of carboxyl groups, for the complexation of 9- $N$-butyladenine and biotin methyl ester [103]. The association constant for 25 and 9- $N$-butyladenine was found to be high $\left(3.5 \times 10^{3} \mathrm{M}^{-1}\right)$, which undoubtedly reflects relatively restricted rotation around the $\mathrm{C}_{3}-\mathrm{O}$ and the $\mathrm{C}_{12}-\mathrm{O}$ bonds. 


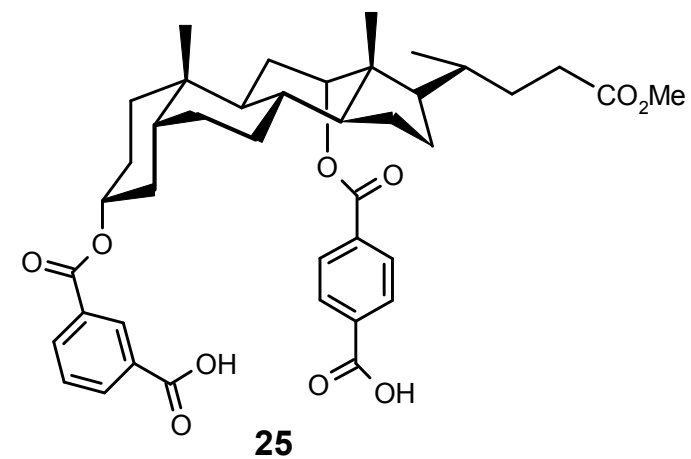<smiles>Nc1ncnc2c1ncn2Cc1ccccc1</smiles>

9-N-butyladenine

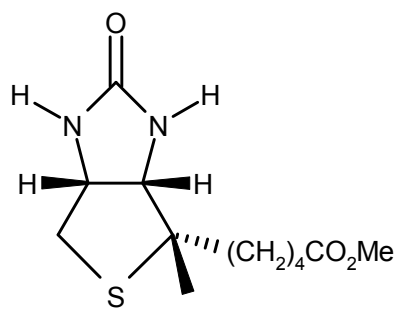

biotin methyl ester

Figure 14. A new bile acid based adenine/biotin receptor 25 [103].

\subsubsection{Other Acyclic Structures}

Davis et al. have designed cholic acid-based podant-type anion binding receptors in which $\mathrm{NH}$ containing groups were attached to the $3 \alpha-, 7 \alpha-$, and $12 \alpha$-positions of steroid nucleus [104]. They have also found that methyl and octyl cholates bind tridentate oxoanions as sulfonates through hydrogen bonding involving the three hydroxyl groups of cholic acid moiety [105]. Broderick and Davis et al. [106] have synthesized the "triamino-analogue" of methyl cholate through several synthetic steps including modified Mitsunobu reactions [107]. Davis and Perez-Payan have later managed to raise the overall yield of this compound to 45\% [108]. Furthermore, Li et al. have prepared other triamine derivatives of cholic acid [109]. The positioning of three co-directed amino groups on a rigid steroidal skeleton suggests further applications to these compounds and their related derivatives in the synthesis of novel receptors. Vandenburg et al. [110] have observed that cationic facial amphiphile (26, Figure 15 ) is exceptionally good compound at promote non-leaky vesicle fusion as well as human cell transfection.

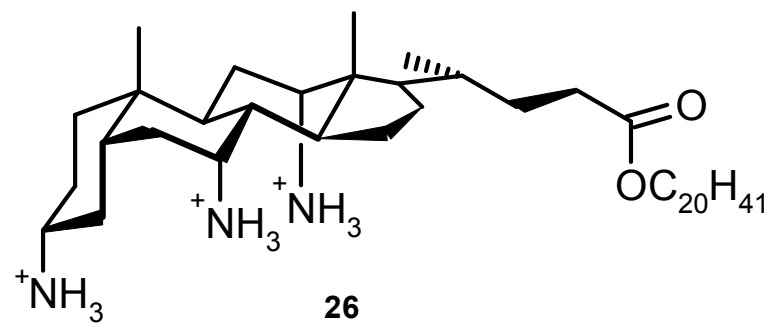

Figure 15. A novel cationic facial amphiphile [110].

Davis and Lawless have prepared steroidal guanidinium receptors, which extract $N$-acetyl- $\alpha$-amino acids from an aqueous medium into $\mathrm{CHCl}_{3}$ with enantiomeric excesses of up to $80 \%$ [111]. In Figure 16 is presented one of these guanidium receptors 27. 


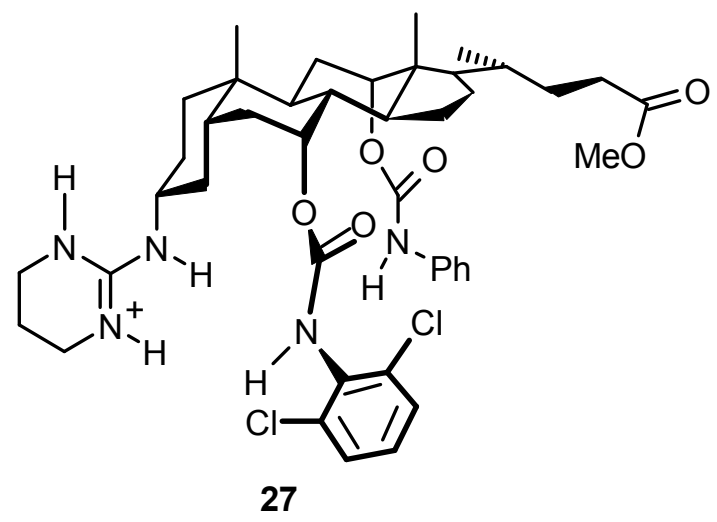

Figure 16. A steroidal guanidinium receptor [111].

Maitra et al. have reported the synthesis of the first bile acid-based chiral dendrons [112]. These relative small oligomers are of considerable interest because of their shape and nanometric dimensions. One of these dendritic species $\mathbf{2 8}$ is presented in Figure 17. Maitra et al. have also demonstrated that donor substituted (pyrene group at the 3-position) bile acid derivatives can gelatinize certain organic solvents, such as primary alcohols, in the presence of trinitrofluorenone [113].

We have synthesized 2,2'-bipyridine-4,4'-dicarboxylates (29a-d, Figure 18) [114] of four bile acid methyl esters from 2,2'-bipyridine-4,4'-dicarboxylic acid and corresponding bile acid methyl esters by Yamaguchi [52] reaction. Distinct from our other synthesized bile acid-based dimers [84-85, 97-99], the most favoured conformation of 29a, obtained from the semi-empirical PM3 calculations, is open ( $\int$-type) structure. Most probably this is caused by the lack of aromatic rings in the heads of the dimer which would stabilize the cleft-type conformation.

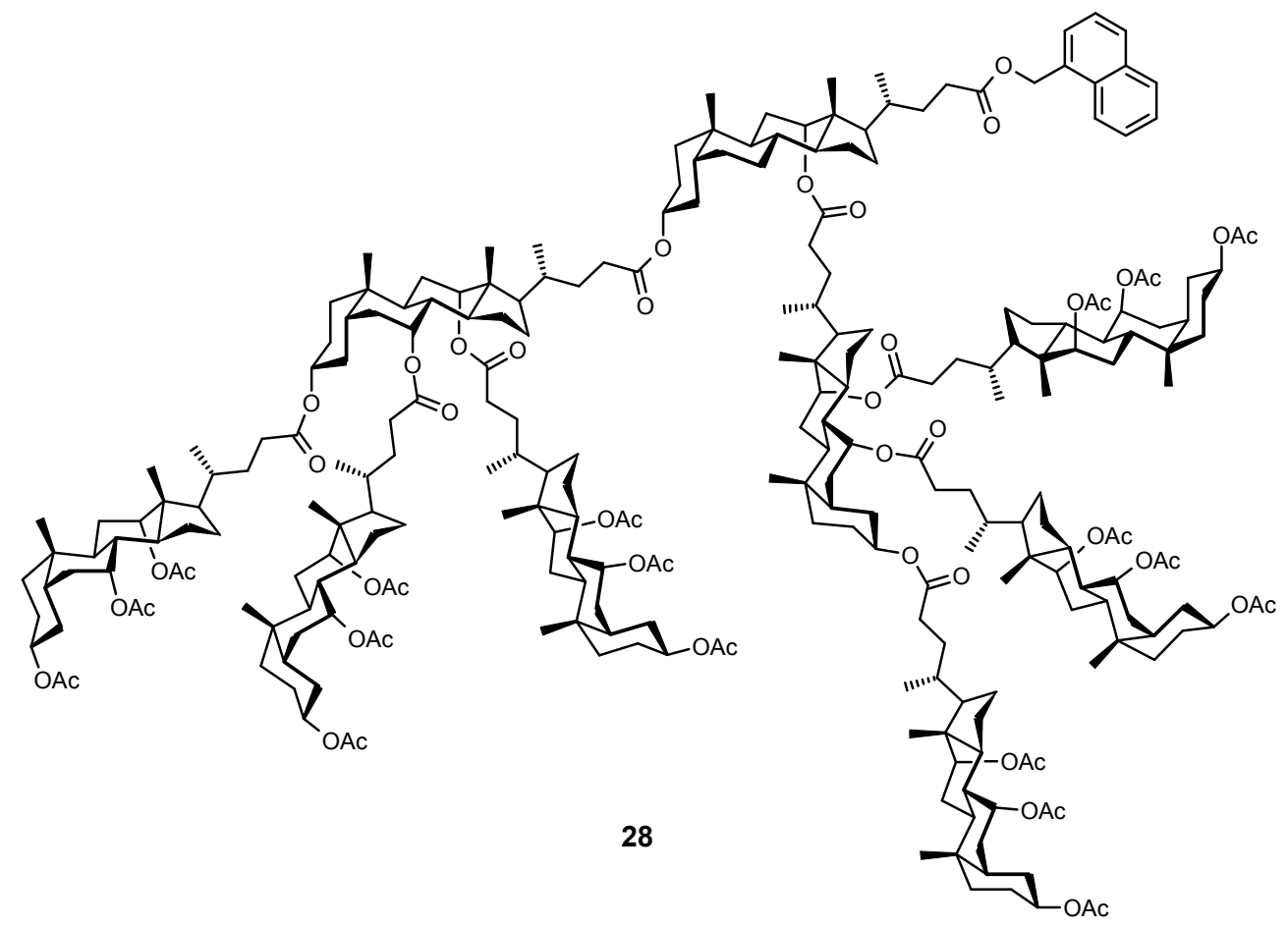

Figure 17. A bile acid-based chiral dendron [112]. 


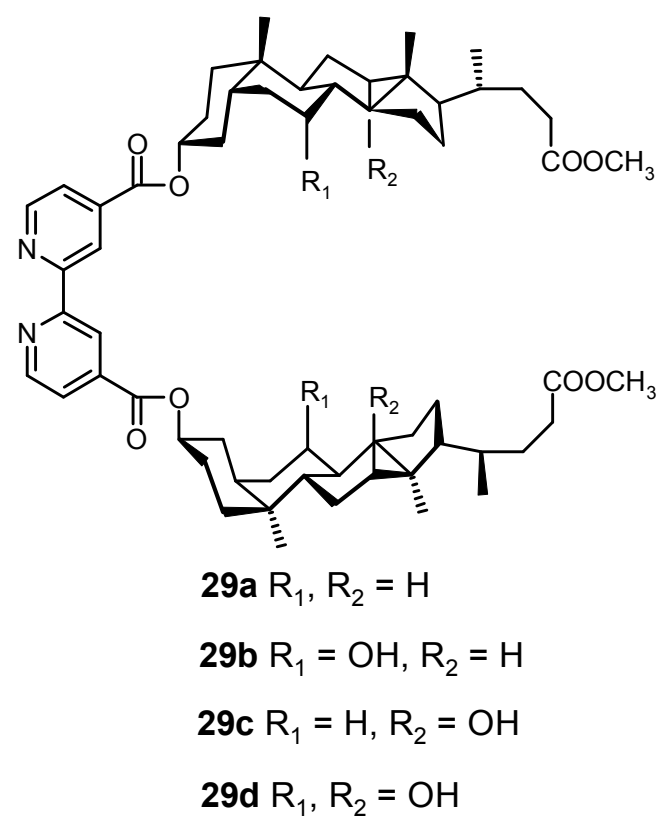

Figure 18. 2,2'-Bipyridine-4,4'-dicarboxylates 29a-d of four bile acid methyl esters [114].

We have also prepared lithocholic acid and deoxycholic acid $N$-(2-aminoethyl)amides (30a-b, Figure 19) and investigated their $\mathrm{Cd}^{2+}$-cation binding properties by NMR measurements and MO calculations [115]. We observed that the bile acid moiety have some influence on the complex formation because the deoxycholic derivative 30b complexed $\mathrm{Cd}^{2+}$-cation remarkably easier than the corresponding lithocholic acid derivative 30a. This can be explain by solvent effects and differences in molecular self-association properties.

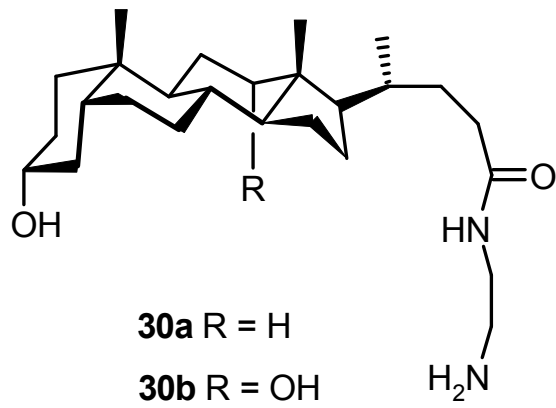

Figure 19. Structures of bile acid $N$-(2-aminoethyl)amides [115].

Other recently published acyclic bile acid-based applications are bile acid-based polymers [116] and copolymers [117], bile acid 24-acyl glucuronides [118], and cholic acid, spermidine, and 5dimethylamino-1-naphthalenesulfonyl derived umbrella-type conjugates [119-120]. 


\subsection{Inclusion Complexes}

Miyata et al. have broadly studied the inclusion complexation of bile acids and their derivatives [121-127]. They have prepared bile acid-based multinuclear inclusion compounds with a variety of organic substances. The channels in the crystal structures of some of these inclusion compounds can perform efficient chiral recognition of some substrates, for example lactones [122]. Gdaniec et al. have also investigated bile acid-based inclusion complexes and found optical activity in formally achiral guest molecules, aromatic ketones, included in the crystal lattice of bile acids [128]. They have also reported on enantioselective inclusion complexation of $N$-nitrosopiperidines by bile acids [129].

\subsection{Bile Acids in Combinatorial Chemistry}

Combinatorial libraries are powerful tools in molecular recognition chemistry. Still et al. [130-131] and Wess et al. [132] have previously created $5 \alpha$ - and 5 $\beta$-chenodeoxycholic acid-based receptor libraries. Barry and Davis et al. have synthesized two methyl cholate derivatives (31a-b, Figure 20) with three independently-addressable, rigidly-positioned functional groups [133]. The free acid of 31b has been used in constructing the hexapeptide library containing 729 compounds [134]. The previously mentioned "triaza-analogue" of methyl cholate $[106,108]$ seems also to be a versatile starting material for combinatorial libraries.

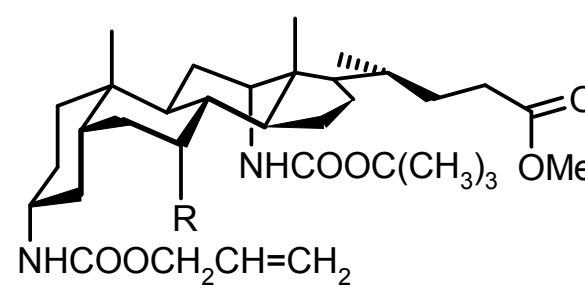

$31 \mathrm{a} \mathrm{R}=\mathrm{OH}$ 31b $\mathrm{R}=\mathrm{OCOCH}_{3}$

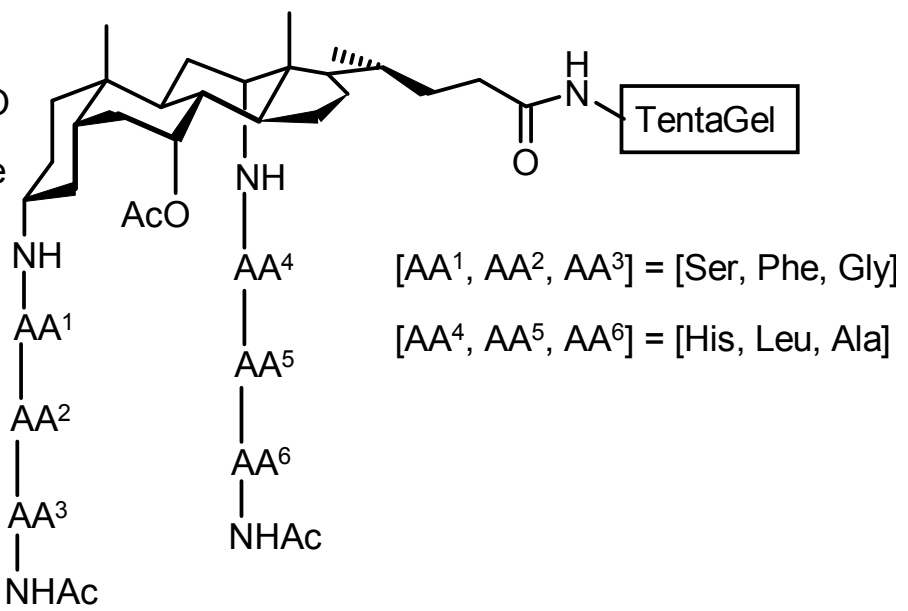

the hexapeptide library

Figure 20. Trifunctional bile acid-based scaffolds 31a-b and the hexapeptide library constructed from the free acid of 31b [133-134]. ( $\mathrm{Ser}=$ serine, Phe = phenylalanine, Gly = glysine, His = histidine, Leu $=$ leucine, Ala = alanine). 


\section{The Latest Spectroscopic and Computational Studies of Bile Acids and Their Derivatives}

\subsection{NMR Spectroscopy}

Due to strong overlap of the peaks, the full assignments of the ${ }^{1} \mathrm{H}-\mathrm{NMR}$ spectra of bile acids and their derivatives is not simple even at the highest field strengths and using the 2D COSY [135] method. However, some complete ${ }^{1} \mathrm{H}-\mathrm{NMR}$ resonance assignments of bile acid derivatives have been made [136-139]. Reynolds et al. have demonstrated [140] that HSQC-TOCSY spectra provide a useful method for the determination of ${ }^{1} \mathrm{H}$ multiplet structure and consequent assignments of individual $\mathrm{CH}_{2}$ protons as axial or equatorial in fused cyclohexane rings. By this and related techniques, they have totally assigned ${ }^{1} \mathrm{H}-\mathrm{NMR}$ spectra of marine sterol clionasterol. Yim et al. have studied [141] inclusion reactions of $\beta$-cyclodextrin with several dihydroxycholate ions by ${ }^{1} \mathrm{H}-\mathrm{NMR}$ spectroscopy taking advantage of separate $18-\mathrm{CH}_{3}$ signals for complexed and free dihydroxylate ions. Bortolini et al. have analyzed [142] the region 2.5-3.0 ppm of the ${ }^{1} \mathrm{H}-\mathrm{NMR}$ spectra of oxo bile acids. The chemical shifts and the multiplicity of the signals in that region are used to characterize the number and position of the oxidation sites.

Total assignations of the ${ }^{13} \mathrm{C}-\mathrm{NMR}$ spectra of steroids have been done over 20 years and a great number of the ${ }^{13} \mathrm{C}$-NMR shift data of bile acids and their derivatives have been published [58-62, 143149]. Dias et al. have identified a diagnostic ${ }^{13} \mathrm{C}$-NMR $\gamma$-oxygen shielding effect which in addition to the deshielding effect on the carbon bearing the electronegative oxygen identifies whether this substituent is oriented axial or equatorial [149].

Publications concerning ${ }^{15} \mathrm{~N}$ - and ${ }^{17} \mathrm{O}-\mathrm{NMR}$ chemical shifts of bile acid-based compounds are very rare. We have presented some ${ }^{15} \mathrm{~N}-\mathrm{NMR}$ data of bile acid derivatives [85, 98, 115] and we [150] and Smith et al. [151] have collected the ${ }^{17} \mathrm{O}-\mathrm{NMR}$ chemical shifts of some bile acid derivatives and other steroidal compounds. We have also used ${ }^{113} \mathrm{Cd}-\mathrm{NMR}$ spectroscopy to investigate $\mathrm{Cd}^{2+}$-cation complexation of above mentioned bile acid $N$-(2-aminoethyl)amides (30a-b, Figure 19) [115].

\subsection{Mass Spectroscopy}

The first studies of the mass spectra of bile acids were performed already 40 years ago. In 1988 Lawson and Setchell reviewed broadly [152] the general fragmentation of bile acid derivatives in mass spectrometer and the use of mass spectroscopy in the determination of bile acids in biological fluids.

Electron ionization (EI) techniques have showed to be of the important diagnostic value in characterising different bile acids and their derivatives. Dias and Nassim have showed through extensive deuterium labelling that the successive EI induced loss of water or HOAc occurs sequentially from the 12-OH, 7-OH, and 3-OH or 12-OAc, 7-OAc, and 3-OAc in that precise order [153-154]. This identifies many structural origins of many ions facilitating structural assignments. For example, $\gamma$ acetoxy ketones lose the acetyl radical by prior transfer of a $\gamma$-hydrogen to the ionized ketone carbonyl and $\alpha$-acetoxy ketones lose the ketene by prior transfer of an acetoxy $\alpha$-hydrogen to the ionized ketone carbonyl.

However, from the supramolecular point of view modern MS-techniques such as electrospray ionization (ESI) and matrix-assisted laser desorption ionization-time-of-light (MALDI-TOF) are more 
important than EI MS. The advantages of ESI and MALDI-TOF are their capabilities for a softer ionization of macromolecules thus allowing their molecular weight determination and even to study the complex or adduct formation between steroidal hosts and guests (small molecules or cations).

ESI has become a common technique in mass spectrometry during the last half decade [72]. As ions are generated directly from the aqueous solutions with only mild heating, ESI MS is suitable for the study of the intermolecular processes. As ESI MS requires only a small amount of material and allows rapid analysis, it has the potential to become a powerful technique for the analysis of the binding interactions. As mentioned before, Brady and Sanders have applied ESI MS to quantifying the alkali metal ion binding properties of neutral monomeric and macrocyclic cholic acid derivatives [72]. We have used ESI MS in the determination of exact molecular masses of bile acid $N$-(2-aminoethyl)amides (30a-b, Figure 19) [115] and cholaphanes (14b-c, Scheme 4) [86]. We also used ESI MS to investigate cation binding properties of $\mathbf{1 4 b}$ and $\mathbf{1 4 c}$ and found that $\mathbf{1 4 b}$ shows a special affinity towards potassium cation while $\mathbf{1 4 c}$ possesses significant proton and sodium cation recognition properties [86].

MALDI-TOF is another broadly used technique in the determination of molecular masses of the bile acid derivatives. It has been used in the determination of molecular masses of lithocholic acidpiperazine diamide and lithocholic acid ethane-1,2-diol diester and their derivatives (Scheme 4 and Figure 12) [85, 97-99], bile acid-based chiral dendrons (Figure 17) [112], 2,2'-bipyridine-4,4'dicarboxylates of bile acid methyl esters (29a-d, Figure 20) [114], and bile acid-based polymers [116].

\subsection{Computational Methods}

Computational methods are very useful in the design of novel supramolecular structures and especially when elaborating host molecules for binding different kinds of guest. Theoretical calculations make it possible to estimate whether there is enough space in the cavity of the cyclic host molecule for a desired guest, or in the case of tweezers, whether the heads of the tweezers are in a suitable mutual position for binding the guest molecule or ion between them. This offers a way to reduce tedious synthetic work. Bile acid-based receptors are often so large that ab initio methods are too slow to be used for the whole molecule. Thus it is more efficient to optimize the complete structure first semi-empirically and/or using molecular mechanics and then continue the optimization at ab initio level for the most important substructure of the molecule.

Rao and Maitra minimized, by using PCMODEL software, all possible benzenedicarboxylic acid pair combinations in the process of designing a tweezers-type, bile acid-based adenine/biotin receptor (25, Figure 14) [103]. They found that only one of the nine possible combinations possessed the correct orientation of the carboxyl groups required to bind adenine. This reduced considerably the synthetic work required. Davis et al. have used MCMM employing MacroModel software in optimizing the structure of the complex between methyl cholate and methanesulfonate anion [105] and of the complex between steroidal guanidinium receptor (27, Figure 16) and $N$-acetyl-L-valinate [111]. We have optimized the structures of our synthesized bile acid derivatives and studied their cation binding properties by semi-empirical PM3 method by using SPARTAN (Version 5.0) [155] and Gaussian 94 [156] or Gaussian 98 [157] software. The most important substructures of the energetically most 
favoured conformers, suggested by the PM3 method, were studied at ab initio/HF level of theory [8586, 98-99, 114-115].

Quantum chemical prediction of NMR chemical shifts has become a very active area of research within past decade. ${ }^{1} \mathrm{H},{ }^{13} \mathrm{C},{ }^{15} \mathrm{~N}$, and ${ }^{17} \mathrm{O}$ chemical shifts of a very large variety of compounds have been calculated and agree well with experimental data. We have used the geometries of the ab initio level optimized substructures of the $\mathrm{Ag}^{+}$- and $\mathrm{Cd}^{2+}$-complexes of bile acid derivatives in computing the ${ }^{13} \mathrm{C}-\mathrm{NMR}$ chemical shift changes caused by metal ion complexation and observed that calculated and experimental ${ }^{13} \mathrm{C}$-NMR chemical shift changes are qualitatively in agreement with each other [98, 115]. The GIAO method seems to be the most straightforward formulation and it has become the most widely used approach in recent years [158-160]. Smith has used [160] the DFT GIAO method to calculate the ${ }^{13} \mathrm{C}-\mathrm{NMR}$ chemical shifts of estrone and cholesterol with satisfactory results.

\section{Summary}

Novel, bile acid moieties containing structures presented in this review have a great deal of potential from the molecular and ionic recognition point of view. Compounds based on bile acids can further be used in studies aimed at finding novel catalysts and amphiphiles and constructing scaffolds for the assembly of combinatorial libraries. Bile acids have also become important tools in medicinal chemistry. Combinations of bile acids and drugs can lead to liver-specific pharmaceuticals or cholesterol-lowering agents or improve the resorption of poorly absorbable drugs. By varying the bile acid and the bridging groups of the cyclic and cleft-type structures, it is possible to prepare many other interesting bile acid-based molecular assemblies for these purposes.

\section{References and Notes}

1. Rebek, J. Jr. Angew. Chem. Int. Edit. Engl. 1990, 29, 245.

2. Lehn, J.-M. Angew. Chem. Int. Edit. Engl. 1990, 29, 1304.

3. Schneider, H.-J. Angew. Chem. Int. Edit. Engl. 1991, 30, 1417.

4. Diederich, F. N. Cyclophanes, Royal Society of Chemistry, Cambridge, 1991.

5. Vögtle, F. Supramolecular Chemistry, Wiley, New York, 1991.

6. Anelli, P. L.; Ashton, P. R.; Ballardini, R.; Balzani, V.; Delgado, M.; Gandolfi, M. T.; Goodnow, T. T.; Kaifer, A. E.; Philp, D.; Pietraszkiewicz, M.; Prodi, L.; Reddington, M. V.; Slawin, A. M. Z.; Spencer, N.; Stoddart, J. F.; Vicent, C.; Williams, D. J. J. Am. Chem. Soc. 1992, 114, 193.

7. Seel, C.; Vögtle, F. Angew. Chem. Int. Edit. Engl. 1992, 31, 528.

8. Davis, A. P. Chem. Soc. Rev. 1993, 22, 243.

9. Lehn, J.-M. Supramolecular Chemistry; VCH: Weinheim, 1995.

10. Lehn, J.-M.; Atwood, J. L.; Davies, J. E. D.; MacNicol, D. D.; Vögtle, F. Eds. Comprehensive Supramolecular Chemistry, Pergamon, Oxford, 1996.

11. Li, Y.; Dias, J. R. Chem. Rev. 1997, 97, 283.

12. Wallimann, P.; Marti, T.; Fürer, A.; Diederich, F. Chem. Rev. 1997, 97, 1567.

13. Antonisse, M. M. G.; Reinhoudt, D. N. Chem. Commun. 1998, 443. 
14. Diederich, F.; Gomez-Lopez, M. Chem. Soc. Rev. 1999, 28, 263.

15. MacGillivray, L. R.; Atwood, J. L. Angew. Chem. Int. Edit. Engl. 1999, 38, 1018.

16. Davis, A. P.; Wareham, R. S. Angew. Chem. Int. Edit. Engl. 1999, $38,2978$.

17. Newkome, G. R.; He, E.; Moorefield, C. N. Chem. Rev. 1999, 99, 1689.

18. Rudkevich, D. M.; Rebek, J. Jr. Eur. J. Org. Chem. 1999, 1991.

19. Rebek, J. Jr. Chem. Commun. 2000, 637.

20. Schneider, H.-J.; Eblinger, F.; Sirish, M. Adv. Supramol. Chem. 2000, 6, 185.

21. Philp, D.; Stoddart, J. F. Angew. Chem. Int. Edit. Engl. 1996, 35, 1155.

22. Gomez-Lopez, M.; Stoddart, J. F. Bull. Soc. Chim. Belg. 1997, 106, 491.

23. Balzani, V.; Gomez-Lopez, M.; Stoddart, J. F. Acc. Chem. Res. 1998, 31, 405.

24. Sauvage, J.-P. Acc. Chem. Res. 1998, 31, 611.

25. Mao, C.; Sun, W.; Shen, Z.; Seeman, N. C. Nature 1999, 397, 144.

26. Davis, A. P. Nature 1999, 401, 120.

27. Kelly, T. R.; De Silva, H.; Silva, R. A. Nature 1999, 401, 150.

28. Koumura, N.; Zijlstra, R. W. J.; van Delden, R. A.; Harada, N.; Feringa, B. L. Nature 1999, 401, 152.

29. Raymo, F. M.; Stoddart, J. F. Chem. Rev. 1999, 99, 1643.

30. Feringa, B. L.; van Delden, R. A.; Koumura, N.; Geertsema, E. M. Chem. Rev. 2000, 100, 1789.

31. Davis, A. P.; Bonar-Law, R. P.; Sanders, J. K. M. In Comprehensive Supramolecular Chemistry, Atwood, J. L.; Davis, J. E. D.; Macnicol, D. D.; Vögtle F., Eds., Elsevier: Oxford, 1996., Vol. 4, pp. 257-286.

32. Miyata, M.; Sada, K. In Comprehensive Supramolecular Chemistry; Atwood, J. L.; Davis, J. E. D.; Macnicol, D. D.; Vögtle, F. Eds. Elsevier, Oxford, 1996., Vol. 6, pp. 147-176.

33. Tamminen, J. PhD Thesis, Department of Chemistry, University of Jyväskylä, Research Report No. 78: Jyväskylä, 2000.

34. Gao, H.; Dias, J. R. Org. Prep. Proced. Int. 1999, 31, 145.

35. Kritchevsky, D.; Nair, P. P. In The Bile Acids: Chemistry, Physiology, and Metabolism; Nair, P. P.; Kritchevsky, D., Eds., Plenum, New York, 1971., Vol. 1, p. 3.

36. Enhsen, A.; Kramer, W.; Wess, G. Drug Discovery Today 1998, 3, 409.

37. Kramer, W.; Wess, G.; Schubert, G.; Bickel, M.; Girbig, F.; Gutjahr, U.; Kowalewski, S.; Baringhaus, K.-H.; Enhsen, A.; Glombik, H.; Müllner, S.; Neckermann, G.; Schulz, S.; Petzinger, E. J. Biol. Chem. 1992, 267, 18598.

38. Hofmann, A. F. News Physiol. Sci. 1999, 14, 24.

39. Hofmann, A. F. Ital. J. Gastroenterol. 1995, 27, 106.

40. Berlati, F.; Ceschel, G.; Clerici, C.; Pellicciari, R.; Roda, A.; Ronchi, C. WO 94001261994.

41. Marples, B. A.; Stretton, R. J. WO 90132981990.

42. Berlati, F.; Ceschel, G.; Roda, A.; Roda, E.; Ronchi, C. WO 94001551994.

43. Swaan, P. W.; Hillgren, K. M.; Szoka Jr, F. C.; Øie, S. Bioconjug. Chem. 1997, 8, 520.

44. Sliedregt, L. A. J. M.; Rensen, P. C. N.; Rump, E. T.; van Santbrink, P. J.; Bijsterbosch, M. K.; Valentijn, A. R. P. M.; van der Marel, G. A.; van Boom, J. H.; van Berkel, T. J. C.; Biessen, E. A. L. J. Med. Chem. 1999, 42, 609. 
45. Kramer, W.; Glombik, H. DE 19824123A1 1999.

46. Geall, A. J.; Al-Hadithi, D.; Blagbrough, I. S. Chem. Commun. 1998, 2035.

47. Ruff, M. R.; Hill, J. M.; Kwart, L. D.; Pert, C. B. US 54460261995.

48. Li, C.; Peters, A. S.; Meredith, E. L.; Allman, G. W.; Savage, P. B. J. Am. Chem. Soc. 1998, 120, 2961.

49. Li, C.; Budge, L. P.; Driscoll, C. D.; Willardson, B. M.; Allman, G. W.; Savage, P. S. J. Am. Chem. Soc. 1999, 121, 931.

50. Campazzi, E.; Cattabriga, M.; Marvelli, L.; Marchi, A.; Rossi, R.; Pieragnoli, M. R.; Fogagnolo, M. Inorg. Chim. Acta 1999, 286, 46.

51. Bell, D. A.; Anslyn, E. V. In Comprehensive Supramolecular Chemistry, Atwood, J. L.; Davis, J. E. D.; Macnicol, D. D.; Vögtle F. Eds., Elsevier, Oxford, 1996., Vol. 2, pp. 439-475.

52. Inanaga, J.; Hirata, K.; Saeki, H.; Katsuki, T.; Yamaguchi, M. Bull. Chem. Soc. Jpn. 1979, 52, 1989.

53. Lappalainen, K.; Kolehmainen, E.; Šaman, D. Spectrochim. Acta, Part A 1995, 51, 1543.

54. Lappalainen, K.; Kolehmainen, E.; Kotoneva, J. Magn. Res. Chem. 1996, 34, 316.

55. Lappalainen, K.; Kolehmainen, E. Liebigs Annalen-Recueil 1997, 1965.

56. Bonar-Law, R. P.; Sanders, J. K. M. Tetrahedron Lett. 1992, 33, 2071.

57. Bonar-Law, R. P.; Sanders, J. K. M. Tetrahedron Lett. 1993, 34, 1677.

58. Li, Y.; Dias, J. R. Synthesis 1997, 425.

59. Gao, H.; Dias, J. R. Synth. Commun. 1997, 27, 757.

60. Gao, H.; Dias, J. R. New J. Chem. 1998, 579.

61. Gao, H.; Dias, J. R. Eur. J. Org. Chem. 1998, 719.

62. Gao, H.; Dias, J. R. Croatica Chemica Acta 1998, 71, 827.

63. Bonar-Law, R. P.; Sanders, J. K. M. J. Chem. Soc., Chem. Commun. 1991, 574.

64. Bonar-Law, R. P.; Mackay, L. G.; Sanders, J. K. M. J. Chem. Soc., Chem. Commun. 1993, 456.

65. Mackay, L. G.; Bonar-Law, R. P.; Sanders, J. K. M. J. Chem. Soc., Perkin Trans. 1 1993, 1377.

66. Bonar-Law, R. P.; Mackay, L. G.; Walter, C. J.; Marvaud, V.; Sanders, J. K. M. Pure Appl. Chem. 1994, 66, 803.

67. Bonar-Law, R. P.; Sanders, J. K. M. J. Am. Chem. Soc. 1995, 117, 259.

68. Bonar-Law, R. P.; Sanders, J. K. M. J. Chem. Soc., Perkin Trans. 1 1995, 3085.

69. Bonar-Law, R. P. J. Am. Chem. Soc. 1995, 117, 12397.

70. Brady, P. A.; Bonar-Law, R. P.; Rowan, S. J.; Suckling, C. J.; Sanders, J. K. M. Chem. Commun. 1996, 319.

71. Brady, P. A.; Sanders, J. K. M. J. Chem. Soc., Perkin Trans. 1. 1997, 3237.

72. Brady, P. A.; Sanders, J. K. M. New J. Chem. 1998, 411.

73. Bonar-Law, R. P.; Davis, A. P. J. Chem. Soc., Chem. Commun. 1989, 1050.

74. Bonar-Law, R. P.; Davis, A. P.; Murray, B. A. Angew. Chem. Int. Edit. Engl. 1990, 29, 1407.

75. Bhattarai, K. M.; Bonar-Law, R. P.; Davis, A. P.; Murray, B. A. J. Chem. Soc., Chem. Commun. $1992,752$. 
76. Bonar-Law, R. P.; Davis, A. P. Tetrahedron 1993, 49, 9829.; Bonar-Law, R. P.; Davis, A. P. Tetrahedron 1993, 49, 9845.; Bonar-Law, R. P.; Davis, A. P.; Dorgan, B. J. Tetrahedron 1993, 49, 9855.

77. Davis, A. P.; Walsh, J. J. Chem. Commun. 1996, 449.

78. Davis, A. P.; Menzer, S.; Walsh, J. J.; Williams, D. J. Chem. Commun. 1996, 453.

79. Bhattarai, K. M.; Davis, A. P.; Perry, J. J.; Walter, C. J. J. Org. Chem. 1997, 62, 8463.

80. Albert, D.; Feigel, M. Tetrahedron Lett. 1994, 35, 565.

81. Albert, D.; Feigel, M. Helv. Chim. Acta 1997, 80, 2168.

82. Albert, D.; Feigel, M.; Benet-Buchholz, J.; Boese, R. Angew. Chem. Int. Edit. Engl. 1998, 37, 2727.

83. Pandey, P. P.; Singh, R. B. Tetrahedron Lett. 1997, 38, 5045.

84. Kolehmainen, E.; Tamminen, J.; Lappalainen, K.; Torkkel, T.; Seppälä, R. Synthesis 1996, 1082.

85. Tamminen, J.; Kolehmainen, E.; Haapala, M.; Linnanto, J. Synthesis 2000, 1464.

86. Haapala, M.; Kolehmainen, E.; Tamminen, J.; Kauppinen, R.; Linnanto, J.; Virtanen, E.; Suontamo, R.; Vainiotalo, P. Mater. Sci. Eng., C, in press.

87. Maitra, U.; Balasubramanian, S. J. Chem. Soc., Perkin Trans. 1 1995, 83.

88. Maitra, U. Curr. Sci. 1996, 71, 617.

89. Maitra, U.; Bag, B. G. J. Org. Chem. 1994, 59, 6114.

90. Maitra, U.; D'Souza, L. J.; Kumar, P. V. Supramol. Chem. 1998, 10, 97.

91. Kohmoto, S.; Fukui, D.; Nagashima, T.; Kishikawa, K.; Yamamoto, M.; Yamada, K. Chem. Commun. 1996, 1869.

92. Irie, S.; Yamamoto, M.; Kishikawa, K.; Kohmoto, S.; Yamada, K. Synthesis 1996, 1135.

93. Kikuchi, J.-I.; Murakami, Y. J. Inclusion Phenom. Mol. Recognit. Chem. 1998, 32, 209.

94. Davis, A. P.; Gilmer, J. F.; Perry, J. J. Angew. Chem. Int. Edit. Engl. 1996, 35, 1312.

95. Kohmoto, S.; Sakayori, K.; Kishikawa, K.; Yamamoto, M. J. Chem. Soc., Perkin Trans. 2 1999, 833.

96. McKenna, J. McKenna, J. M.; Thornthwaite, D. W. J. Chem. Soc., Chem. Commun. 1977, 809.

97. Tamminen, J.; Lappalainen, K.; Laihia, K.; Mänttäri, P.; Salo, H.; Kolehmainen, E. Magn. Res. Chem. 1999, 37, 163.

98. Kolehmainen, E.; Tamminen, J.; Kauppinen, R.; Linnanto, J. J. Inclusion Phenom. Macrocyclic Chem. 1999, 35, 75.

99. Tamminen, J.; Kolehmainen, E.; Linnanto, J.; Salo, H.; Mänttäri, P. Magn. Res. Chem. 2000, 38, 877.

100. Maitra, U.; D'Souza, L. J. J. Chem. Soc., Chem. Commun. 1994, 2793.

101. D'Souza, L. J.; Maitra, U. J. Org. Chem. 1996, 61, 9494.

102. Maitra, U.; Rao, P.; Kumar P, V.; Balasubramanian, R.; Mathew, L. Tetrahedron Lett. 1998, 39, 3255.

103. Rao, P.; Maitra, U. Supramol. Chem. 1998, 9, 325.

104. Davis, A. P.; Perry, J. J.; Williams, R. P. J. Am. Chem. Soc. 1997, 119, 1793.

105. Davis, A. P.; Perry, J. J.; Wareham, R. S. Tetrahedron Lett. 1998, 39, 4569.

106. Broderick, S.; Davis, A. P.; Williams, R. P. Tetrahedron Lett. 1998, 39, 6083. 
107. Davis, A. P.; Dresen, S.; Lawless, L. J. Tetrahedron Lett. 1997, 38, 4305.

108. Davis, A. P.; Pérez-Payán, M. N. Synlett 1999, 991.

109. Li, C.; Ur-Rehman, A.; Dalley, N. K.; Savage, P. B. Tetrahedron Lett. 1999, 40, 1861.

110. Vandenburg, Y. R.; Smith, B. D.; Pérez-Payán, M. N.; Davis, A. P. J. Am. Chem. Soc. 2000, 122, 3252.

111. Davis, A. P.; Lawless, L. J. Chem. Commun. 1999, 9.

112. Balasubramanian, R.; Rao, P.; Maitra, U. Chem. Commun. 1999, 2353.

113. Maitra, U.; Kumar, P. V.; Chandra, N.; D’Souza, L. J.; Prasanna, M. D.; Raju, A. R. Chem. Commun. 1999, 595.

114. Tamminen, J.; Kolehmainen, E.; Haapala, M.; Salo, H.; Linnanto, J. ARKIVOC 2000, 1, 90.

115. Tamminen, J.; Kolehmainen, E.; Linnanto, J.; Vainiotalo, P.; Vuorikoski, S.; Kauppinen, R. J. Inclusion Phenom. Macrocyclic Chem. 2000, 37, 121.

116.Zuluaga, F.; Valderruten, N. E.; Wagener, K. B. Polym. Bull. 1999, 42, 41.

117.Zhang, Y. H.; Akram, M.; Liu, H. Y.; Zhu, X. X. Macromol. Chem. Phys. 1998, 199, 1399.

118. Goto, J.; Murao, N.; Oohashi, J.; Ikegawa, S. Steroids 1998, 63, 180.

119. Janout, V.; Lanier, M.; Regen, S. L. J. Am. Chem. Soc. 1996, 118, 1573.

120. Janout, V.; Lanier, M.; Regen, S. L. J. Am. Chem. Soc. 1997, 119, 640.

121. Miyata, M.; Shibakami, M.; Goonewardena, W.; Takemoto, K. Chem. Lett. 1987, 605.

122. Miyata, M.; Shibakami, M.; Chirachanchai, S.; Takemoto, K.; Kasai, N.; Miki, K. Nature 1990, $343,446$.

123. Sada, K.; Shiomi, N.; Miyata, M. J. Am. Chem. Soc. 1998, 120, 10543.

124. Hishikawa, Y.; Aoki, Y.; Sada, K.; Miyata, M. Chem. Lett. 1998, 1289.

125. Hishikawa, Y.; Watanabe, R.; Sada, K.; Miyata, M. Chirality 1998, 10, 600.

126. Miyake, Y.; Hirose, J.; Hasegawa, Y.; Sada, K.; Miyata, M. Chem. Commun. 1998, 111.

127. Sugahara, M.; Sada, K.; Miyata, M. Chem. Commun. 1999, 293.

128. Gdaniec, M.; Polonski, T. J. Am. Chem. Soc. 1998, 120, 7353.

129. Gdaniec, M.; Milewska, M. J.; Polonski, T. Angew. Chem. Int. Edit. Engl. 1999, 38, 392.

130. Boyce, R.; Li, G.; Nestler, H. P.; Suenaga, T.; Still, W. C. J. Am. Chem. Soc. 1994, 116, 7955.

131. Cheng, Y.; Suenaga, T.; Still, W. C. J. Am. Chem. Soc. 1996, 118, 1813.

132. Wess, G.; Bock, K.; Kleine, H.; Kurz, M.; Guba, W.; Hemmerle, H.; Lopez-Calle, E.; Baringhaus, K.-H.; Glombik, H.; Enhsen, A.; Kramer, W. Angew. Chem. Int. Edit. Engl. 1996, 35, 2222.

133. Barry, J. F.; Davis, A. P.; Nieves Pérez-Payan, M.; Elsegood, M. R. J.; Jackson, R. F. W.; Gennari, C.; Piarulli, U.; Gude, M. Tetrahedron Lett. 1999, 40, 2849.

134. De Muynck, H.; Madder, A.; Farcy, N.; De Clercq, P. J.; Nieves Pérez-Payán, M.; Öhberg, L. M.; Davis, A. P. Angew. Chem. Int. Edit. Engl. 2000, 39, 145.

135. Derome, A. E.; Williamson, M. P. J. Magn. Reson. 1990, 88, 177.

136. Kirk, D. N.; Toms, H. C.; Douglas, C.; White, K. A.; Smith, K. E.; Latif, S.; Hubbard, R. W. P. J. Chem. Soc., Perkin Trans. 2 1990, 1567.

137. Iida, T.; Chang, F. C.; Mushiake, K.; Goto, J.; Nambara, T. Magn. Res. Chem. 1993, 31, 645.

138. Liu, M.; Farrant, R. D.; Lindon, J. C.; Nicholson, J. K. Magn. Res. Chem. 1995, 33, 212.

139. Momose, T.; Iida, T.; Mushiake, K.; Goto, J.; Nambara, T. Magn. Res. Chem. 1996, 34, 681. 
140. Reynolds, W. F.; McLean, S.; Tay, L.-L.; Yu, M.; Enriquez, R. G.; Estwick, D. M.; Pascoe, K. O. Magn. Res. Chem. 1997, 35, 455.

141. Yim, C. T.; Zhu, X. X.; Brown, G. R. J. Phys. Chem. B 1999, 103, 597.

142. Bortolini, O.; Carpi, A.; Fantin, G.; Guerrini, A.; Medici, A. Ann. Chim. 1999, 89, 319.

143. Iida, T.; Komatsubara, I.; Yoda, S.; Goto, J.; Nambara, T.; Chang, F. C. Steroids 1990, 55, 530.

144. Blunt, J. W.; Stothers, J. B. Org. Magn. Reson. 1977, 9, 439.

145. Iida, T.; Tamura, T.; Matsumoto, T.; Chang, F. C. Org. Magn. Reson. 1983, 21, 305.

146. Iida, T.; Chang, F. C.; Goto, J.; Nambara, T. Chem. Phys. Lipids 1987, 45, 1.

147. Iida, T.; Goto, J.; Nambara, T. Magn. Res. Chem. 1993, 31, 421.

148. Blossey, E. C.; Ford, W. T.; Periyasamy, M. Magn. Res. Chem. 1991, 29, 190.

149. Dias, J. R.; Gao, H.; Kolehmainen, E. Spectrochim. Acta, Part A 2000, 56, 53.

150. Kolehmainen, E.; Kaartinen, M.; Kauppinen, R.; Kotoneva, J.; Lappalainen, K.; Lewis, P. T.;

Seppälä, R.; Sundelin, J.; Vatanen, V. Magn. Res. Chem. 1994, 32, 441.

151. Smith, L. L.; Herz, J. E.; Ezell, E. L. Steroids 1993, 58, 260.

152. Lawson, A. M.; Setchell, K. D. R. In The Bile Acids: Chemistry, Physiology, and Metabolism;

Setchell, K. D. R.; Kritchevsky, D.; Nair, P. P., Eds., Plenum, New York, London, 1988., Vol. 4, pp. 167-267.

153. Dias, J. R.; Nassim, B. Org. Mass Spectrom. 1978, 13, 402.

154. Dias, J. R.; Nassim, B. J. Org. Chem. 1980, 45, 337.

155. SPARTAN, Version 5.0, Wavefunction Inc., Irvine, CA (1993-1997).

156. Frisch, M. J.; Trucks, G. W.; Schlegel, H. B. et al. GAUSSIAN 94, Revision B.1, Gaussian Inc., Pittsburgh PA (1995).

157. Frisch, M. J.; Trucks, G. W.; Schlegel, H. B. et al. GAUSSIAN 98, Revision A.6, Gaussian Inc., Pittsburgh PA (1998).

158. Lampert, H.; Mikenda, W.; Karpfen, A.; Kählig, H. J. Phys. Chem. A 1997, 101, 9610.

159. Cammi, R.; Mennucci, B.; Tomasi, J. J. Chem. Phys. 1999, 110, 7627.

160. Smith, W. B. Magn. Res. Chem. 1999, 37, 103.

Samples Availability: Not applicable.

(C) 2001 by MDPI (http://www.mdpi.org). Reproduction is permitted for noncommercial purposes. 